\title{
Lisans Düzeyinde Muhasebe Ĕgitimi Alan Öğrencilerde Strese Neden Olan Faktörlerle Derse Yönelik Tutumları Arasındaki İlişkinin Araştırılması*
}

\author{
Selim CENGİZ** \\ Bilgehan TEKIN ${ }^{* * *}$
}

\section{$\ddot{O Z Z E T}$}

$\mathrm{Bu}$ çalışmanın amacı, muhasebe dersi alan lisans ögrencilerinde strese neden olan faktörlerle derse yönelik tutumları arasındaki ilişkinin tespitidir. Araştırmada anket yöntemi kullanılmıştır. Anket, öğrencilerin demografik yapısının belirlenmesi ve strese neden olan faktörler ile muhasebe dersleri ile ilgili tutumlarını tespit etmek için Çankırl Karatekin Üniversitesi İktisadi ve İdari Bilimler Fakültesinde (İIBF) ögrenim gören ögrenciler arasından, kolayda örnekleme yoluyla seçilen 238 öğrenciye uygulanmıştır. Anket soruları, Frekans Analizi, T Testi ve Tek Yönlü Varyans Analizi teknikleri kullanılarak analiz edilmiştir. Çalışma sonucunda, ögrencilerin başarısız olma korkusu ve mezuniyet sonrası ne yapacağını bilememe kaygısı ve öğrenciler arasındaki gruplaşmanın strese neden olan önemli faktörler olduğu belirlenmiştir. Ayrıca muhasebe derslerinin uygulamaya ve kariyer mesleklerine yönelik olmadı̆̆ tespit edilmiştir.

Anahtar Kelimeler: Muhasebe Dersi, Stres Faktörleri, Muhasebe Eğitimi.

JEL Sinıflandırması: A220, M490

A Research To Determine The Perspective And Attitudes Of The Students To The Lesson Who Receive Accounting Education At Undergraduate Level

\section{ABSTRACT}

The purpose of this study is to determine the relationship between the factors causing the stress and the attitudes towards the course in the undergraduate students taking the accounting course. Survey method was used in the research. In order to determine the demographic structure of the students and to determine the attitudes of the students about the factors causing the strasse and the accounting courses, 238 students selected by easy sampling among Çankırı Karatekin University Faculty of Economics and Administrative Sciences (IIIBF) were applied. Survey questions were analyzed using Frequency Analysis, T-Test and One-Way ANOVA. As a result of the study, it was determined that the fear of failure of the students, the anxiety of not knowing what to do after graduation and the grouping among the students were the important factors causing the stress. It has also been found out that accounting courses are not directed towards practice and career professions.

Keywords: Accounting Course, Stress Factors, Accounting Education.

Jel Classification: A220, M490

Makale Gönderim Tarihi: 14.05.2018

Makale Kabul Tarihi: 21.11.2018

\footnotetext{
* Bu çalışma, 7- 9 Nisan 2018 tarihinde gerçekleşen Uluslararası İnsan ve Toplum Bilimleri Sempozyumunda sunulan ve özet bildiri kitapçı̆̆ında basılan çalışmanın yeniden gözden geçirilmiş halidir.

** Doç. Dr., Çankırı Karatekin Üniversitesi, İİBF, Bankacılık ve Finans Bölümü, scengiz@karatekin.edu.tr, ORCID ID: 0000-0002-2013-9590

*** Dr. Öğr.Üyesi, Çankırı Karatekin Üniversitesi, İİBF, İşletme Bölümü, btekin@ karatekin.edu.tr, ORCID ID: 0000-0002-4926-3317
} 


\section{GíRiş}

Muhasebe eğitiminin amac1, eğitim gören öğrencilerin; işletme kararlarına yararlı bilgilerin belirlenmesi, toplanması, işlenmesi, doğruluğun denetlenmesi, raporlar halinde özetlenmesi ve bu raporların incelenmesinden çıkarılan sonuçların karar almada kullanılması konusunda bilgilendirilmesi ve bu bilgilerin uygulanması konusunda eğitilen kişinin yeteneklerinin geliştirilmesi olarak ifade edilebilir. Muhasebe eğitimindeki temel amaç, finansal bilgileri kullanmak durumunda olan öğrencilere muhasebe bilgilerinin doğru ve güvenilir sunulabilmesi konusunda eğitim vermek ve uygulamaları da buna göre yönlendirmektir (Gökçen, 1998: 43-50). Öte yandan, iyi bir muhasebe eğitimi vermek demek yalnızca öğrencileri teorik bilgilerle donatmak anlamına gelmemektedir. Öğrencilere, teorik bilgilerin yanında problem çözme, zamanı etkin kullanma ile iletişim ve takım halinde çalışma gibi yeteneklerde verime amaçlanmalıdır (Erol ve Erkan, 2008: 3). Bu amaç doğrultusunda muhasebe ders içerikleri ve öğrenim çıktılarının da, muhasebe mevzuatı ve uygulama açısından öğrencilerin bilgi, beceri ve yetkinliklerini geliştirecek şekilde belirlenmesi gerekmektedir. Böylece muhasebe derslerinden alınan verim artacak, muhasebe eğitimi alan öğrenciler tercihleri doğrultusunda görev yapacakları işletmelerde veya devlet kurumlarında muhasebe uygulamalarıyla ilgili gerekli bilgi ve beceriye sahip birer meslek mensubu adayı olarak mezun olacaklardır (Yıldız ve Ülkü, 2015: 895). Bu noktada muhasebe eğitiminde cevap aranması gereken sorulardan biri de, dersi alan öğrencilerin strese neden olan faktörle muhasebe derslerine yönelik tutumları arasında bir ilişki var mıdır?

$\mathrm{Bu}$ çalışmanın amacı, üniversitenin farklı bölümlerinde muhasebe dersini alan öğrencilerin; muhasebe eğitimine yönelik tutumları ile strese neden olan faktörler arasındaki ilişkiyi tespit etmek ve böylelikle lisans düzeyinde muhasebe eğitimi alan öğrencilerin görüşleri alınarak muhasebe eğitiminin gelişmesine katkı sağlamaktır. Bu amaçla öncelikle konuyla ilgili kavramsal çerçeve ve literatür sunulmuş, daha sonra araştırmanın metodolojisi ele alınmış, son olarak da araştırmanın bulgularına, sonuçlarına ve değerlendirmelere yer verilmiştir.

\section{KAVRAMSAL ÇERÇEVE}

\subsection{Muhasebe Eğitimi ve Önemi}

Değişen ve gelişen ekonomik koşullar, bireylerin ve işletmelerin farklılaşan ihtiyaç ve beklentileri, yoğun rekabet ortamları her meslekte olduğu gibi muhasebe mesleğini de etkilemektedir. Özellikle ekonomik yapıların gelişmesi ve değişmesi ile muhasebe mesleğine daha çok görev düşmekte ve bu görevleri yerine getirebilecek nitelikli muhasebe elemanı ihtiyacı da artmaktadır. Dolayısıyla nitelikli personel yetiştirme çabaları muhasebe eğitimini giderek daha önemli hale gelmektedir (Karlıklı, 2016:19). Bu kapsamda muhasebe eğitimi; işletmenin alacağı kararlar için yararlı bilgilerin belirlenmesi, toplanması, ölçülmesi, işlenmesi, kaydedilmesi, doğruluğunun denetlenmesi, açı ve anlaşılır raporlar halinde özetlenmesi, analizi ve analizden elde edilen sonuçların karar almada kullanılması konusunda öğrencilerin bilgilendirilmesi ve bu bilgilerin kullanılması için yeteneklerinin geliştirilmesi şeklinde tanımlanabilmektedir. Muhasebe alanında verilen eğitim, öğrencilere teorik ve teknik muhasebe bilgisi, entelektüel beceriler, mesleki değer ve etik konularına ilişkin temel muhasebe bilgilerini kazanmalarını sağlamaktadır (Zeytin, 2016: 150). Muhasebe eğitimi yoğun bir rekabetin yaşandığı mesleki eğitim alanlarından birisidir. Bu durum, finansal 
bilgileri her yönden belirgin ve tarafsız tespit edecek, kaydedecek, yorumlayarak bunlara göre kararlar alacak bireylerin yetiştirilmesinde önemlidir. Etkin bir muhasebe eğitimi, pratik uygulamalar ile teorinin birlikteliğine dayalı olmalıdır ve interaktif öğrenme yöntemleri sağlamak için uygun eğitim yardımları ve ekipman kullanımını gerektirmektedir. Ayrıca muhasebe eğitiminde önemsenmesi gereken hususların başlıcaları; sürekli öğrenme, analiz yapabilme, zaman yönetimi, iletişim, bilgi teknolojileri ve takım halinde çalışmadır (Akbulut vd., 2014: 76-77; Kayıhan ve Tepeli, 2015: 489).

\subsection{Stres Kavramı ve Kapsamı}

Stres, Latince "estrictia" (çekip germe) kavramından gelmekte olup, Fransızca ise "estrece" sözcüğüne dayanan ve 17. yüzy1lda felaket, bela, musibet, dert, keder, elem gibi anlamlarda kullanılmaktaydı. Ancak 18. ve 19. yüzyıllarda stres kavramının anlamı değişmiş olup güç, baskı, zor gibi anlamlarda nesnelere, kişiye, organlara ve ruhsal yapıya yönelik olarak kullanılmıştır. Buna bağlı olarak stres nesne ve kişinin bu tür güçlerin etkisi ile biçiminin bozulmasına, çarpıtılmasına karşı bir direnç anlamında kullanılmaya başlamıştır (Güçlü, 2001: 92; Yıldırım, 2004: 154). Öte yandan stres kavramı, ilk kez Hans Selye (1930) tarafından yapılan çalışma ile birlikte bilimsel literatüre kazandırılmıştır. Selye'ye göre stres, "kişilerin belirli bir soyut veya somut olaylara karşı verdiği ruhsal ve bedensel ile özel bir durumu olmayan tepkiler" bütünü olarak tanımlamıştır (Eren, 2004: 292). Stresle ilgili birçok tanım söz konusudur. Bunlardan bazıları aşağıda özetlenmiştir; "Schermerhorn'a göre stres, "olağanüstü talepler, sınırlamalar veya fırsatlarla yüz yüze gelindiğinde birey tarafından yaşanan bir gerilim durumudur" (Pehlivan 1995: 7). Cüceloğlu ise stresi, bireyin fiziksel ve sosyal çevredeki uyumsuz koşullar nedeniyle, bedensel ve psikolojik sinırlarının ötesinde harcadığ1 gayret olarak tanımlamaktadır (Zeytin ve Gökgöz, 2011: 100). Misırlı (2004)'ya göre stres, insan vücudunun biyolojik ve psikolojik dengesinin bozulması başka bir deyişle, insan sağlığına yönelik baskı veya gerginliğe yönelik işarettir (Mısırlı 2004: 121-122). Hacıhasanoğlu ve Karaca (2014)'ya göre, bireyler üzerinde olumlu ve olumsuz etkilere neden olan stres, organizmanın çevreyle olan etkileşimi olarak tanımlanmaktadır. Ayrıca yazarlar çalışmalarında stresi, bireylerde meydana gelen onları normal faaliyetlerinden sapmaya zorlayan farklı bir durum olarak ifade etmişlerdir. Gümüştekin ve Öztemiz (2005) stresi, bireylerin normal işlevlerinden farklılaşmaya zorlayan değişmeler tarafindan belirlenen ve onların işleriyle ve diğer insanlarla etkileşiminden kaynaklanan durum olarak tanımlamışlardır (Gümüştekin ve Öztemiz, 2005: 272).

\subsection{Strese Neden Olan Faktörler ve Sonuçları}

Genellikle strese neden olan birçok faktör bulunmaktadır. Stresin kaynağ çoğu kez kişisel özelliklerle (huyları, mizaçları, başarı ihtiyacı, sabırsızlık, rekabet etme isteği ve duygusal yapısı, karakterleri ve yetenekleri vb.) ilgilidir (Eren Gümüştekin ve Gültekin, 2010: 4). Strese neden olan faktörler genel olarak şu şekilde sıralanabilir (Kaplanoğlu, 2014: 133): Ailede şiddetli geçimsizlik, ekonomik yetersizlikler, orta yaş bunalımı, şehir hayatının getirdiği zorluklar, örf ve adetler, sosyal ve kültürel değişim, siyasi ve politik belirsizlikler, yabancılaşma, fiziksel şartların yetersizliği, monotonluk, kariyer gelişimi. Öte yandan, stresin kişiler üzerindeki olumsuz sonuçları Tablo 1'de özetlenmiştir (Bekçi vd., 2007: 148-149). 
Tablo 1. Stresin Kişiler Üzerindeki Olumsuz Sonuçları

\begin{tabular}{l|l|l}
\hline Davranışsal & Fizyolojik & Psikolojik \\
\hline Fazla alkol ve sigara kullanımı & Baş ağrısı & Yorgunluk ve Anksiyete \\
Ev ve işyerinde kişilerle zayıf ilişkiler & Sırt Ağrısı ve Kalp hastalığı & Depresyon ve çabuk kızma \\
İş veriminin azalması & Halsizlik ve Yüksek tansiyon & Konsantrasyon Güçlüğü \\
Düşüncesiz duygusal davranışlar & Uyku sorunları & Duyusal çöküntü veya Sıkıntı \\
Evlilik ve aile hayatının bozulması & Hazımsızlık & İştahsızlık ve Algılamada azalma \\
Sosyal yalıtkanlık & Titreme ve Bulantı & Sinirlilik ve İntihar \\
\hline
\end{tabular}

\section{LITERATÜR TARAMASI}

Konuyla ilgili literatür incelendiğinde muhasebe eğitimi alan öğrencilerin derse yönelik beklenti ve tutumlarının araştırıldığı çok sayıda çalışma bulunmaktadır. Ancak muhasebe dersine yönelik tutum ve beklentiler ile öğrencilerdeki stres faktörünün birlikte ve karşılıklı olarak incelendiği çok fazla çalışma bulunmamaktadır. Ayrıca literatürde öğrencilerin stres faktörlerinin incelendiği çalışmalar da yer almaktadır. Mevcut çalışmalar stresin öğrenci yaşam kalitesi, üniversite başarısı ve derslere bakış açıları üzerinde olumsuz bir etkisi olduğunu göstermektedir. Literatürde stres ve öğrencilerin üniversite yaşamları ve başarıları üzerine etkisi konusunu ele alan çok sayıda çalışma bulmak mümkündür. $\mathrm{Bu}$ çalışmalardan bazıları aşağıda özetlenmiştir.

Cahir ve Morris (1991), lisansüstü psikoloji eğitiminde stres faktörlerini araştırmışlardır. Çalışmalarında Psikoloji Öğrenci Stres Anketi (PSSQ) geliştirmişler ve bu anket ile topladıkları veriler üzerinden lisansüstü psikoloji eğitiminin duygusal, finansal ve akademik stres faktörlerinin öğrenciler üzerindeki etkisini araştırmışlardır. Çalışmalarının sonucunda kadın öğrencilerin erkeklere göre daha yüksek stres puanlarına sahip olduklarını tespit etmişlerdir. Abouserie (1994), üniversite öğrencilerinde stres kaynağını ve düzeyini kontrol odağı ve benlik saygısı ilişkisi bakımından araştırmıştır. Araştırma örneklemi, 675 (202 erkek ve 473 kadın ikinci sınıf lisans öğrencisinden oluşmaktadır. Çalışma sonucunda, sınavların ve sonuçlarının öğrencilerin en yüksek stres nedenleri olduğunu tespit etmişlerdir. Bulgular aynı zamanda kadın öğrencilerin erkeklerden daha fazla stresli olduğunu göstermiştir. Sonuçlar ayrıca, kontrol odağı ile akademik stres arasında pozitif yönde anlamlı bir ilişki olduğunu göstermiştir. McEwan ve Goldenberg (1999), Kanada' da 3 üniversitede yüksek lisans seviyesinde eğitim gören hemşirelik öğrencilerinin akademik başarılarına, başarı motivasyonunun ve kaygısının etkisini araştırmışlardır. Çalışma sonucunda durumsal kaygı akademik başarı ile negatif korelasyondayken, sürekli kaygı akademik başarının tek geçerli öngörücüsü olmuştur. Misra vd., (2000), Amerikalı ve uluslararası öğrencilerin akademik stres düzeylerini araştırmışlardır. Amerikalı öğrencilerin, uluslararası öğrencilere göre daha yüksek stres seviyesine sahip olduklarını bulmuşlardır. Robotham (2008) çalışmasında, yükseköğretimde okuyan öğrencilerin yaşadığı stresle ilgili önceki araştırmaları incelemiştir. Son 25 yılda yapılan çalışmaları incelediği çalışmasının sonuçlarına göre üniversite öğrencilerinin stres düzeylerindeki artışın sadece Birleşik Krallık ile sınırlı kalmadığını diğer ülkelerde yapılan çalışmalarda da benzer sonuçların bulunduğunu ifade etmiş̧ir.

Brougham vd., (2009), 166 üniversite öğrencisinin stres faktörlerini (akademisyenler, maddi durum, aile, sosyal etkiler ve günlük hayatın zorlukları) ve stres ile baş etme stratejilerini (kendi kendine yardım, yaklaşım, konaklama, kaçınma ve kendini cezalandırma) 
incelemişlerdir. Çalışmalarının bulgularına göre, kadın öğrenciler, erkeklerden daha yüksek genel stres düzeyine sahiptirler. Ayrıca kadınlar duygu odaklı stresle baş etme stratejilerini daha fazla kullandıklarını tespit etmişlerdir. Gabre ve Kumar (2012), algılanan stresin muhasebe öğrencilerinin akademik performansı üzerindeki etkilerini araştırdıkları çalışmalarında kadın öğrencilerin erkek öğrencilerden daha yüksek stres düzeyine sahip olduklarını bulmuşlardır. Ayrıca stresin akademik performansı olumsuz yönde etkilediğini tespit etmiş̧lerdir. How vd., (2013), muhasebe bölümü öğrencilerinin akademik stresini ölçmeyi amaçlayan bir çalışma yapmışlardır. Çalışma, muhasebe öğrencilerinin akademik stresini ölçen bir ölçeğin geliştirilmesini konu almaktadır. Amerika Birleşik Devletleri'nde 59 muhasebe öğrencisinden topladıkları veriler üzerinden yapılan istatistiksel analizler, aracın muhasebe öğrencilerinin akademik stresinin güvenilir ve geçerli bir ölçeği olduğunu göstermiştir. Stresin kadınlarda erkeklere göre daha yüksek olduğunu tespit etmişlerdir. Aynı zamanda yaşça biraz daha genç öğrencilerde diğerlerine göre daha yüksektir. Aşçı vd., (2015), üniversite öğrencilerinde stres nedenlerinin ve stresle başa çıkma biçimlerinin belirlenmesi amacıyla yaptıkları çalışmada kadın öğrencilerin sosyal destek boyutundan aldıkları puanlar erkek öğrencilere göre, lisansüstü eğitim almak isteyenlerin problem odaklı başa çıkma puanları lisansüstü eğitim almak istemeyenlere göre daha yüksek bulmuşlardır. Çalışmada ilişkilerin çıkara dayanmasını, öğretim elemanlarının öğrenciler arasında ayrım yapmasını ve derslerin yoğunluğunu öğrenciler arasında strese neden olan ilk üç faktör olarak belirlemişlerdir.

Tablo 2'de muhasebe dersini alan öğrencilerin derse yönelik tutum ve beklentilerinin incelendiği çalışmalar özetlenmiştir.

Tablo 2. Konuyla İlgili Literatür Taraması

\begin{tabular}{|c|c|c|c|}
\hline 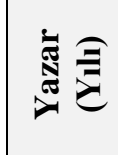 & : & 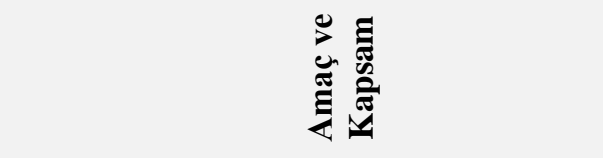 & 离 \\
\hline 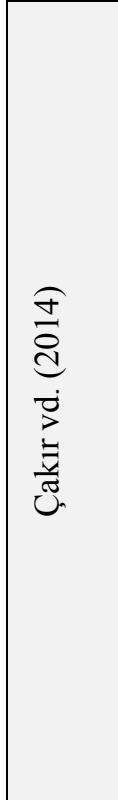 & 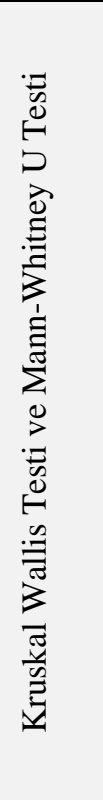 & $\begin{array}{l}\text { Çalışmanın amacı, meslek yüksekokulu } \\
\text { öğrencilerinin muhasebe dersine olan } \\
\text { ilgileri ile muhasebe dersinden } \\
\text { beklentileri arasındaki ilişkileri } \\
\text { araştırmaktır. Çalışmanın kapsamını } \\
\text { Trakya Üniversitesi Uzunköprü Meslek } \\
\text { Yüksekokulu'nda öğrenim gören } 258 \\
\text { öğrenci oluşturmaktadır. }\end{array}$ & $\begin{array}{l}\text { Çalışmanın sonucunda, öğrencilerin \% } \\
\text { 92,2'sinin mezun olduktan sonra eğitim } \\
\text { hayatına devam etmek istediği tespit } \\
\text { edilmiştir. Ankete katılan ögrencilerin } \\
\text { çoğunluğunun daha önce muhasebe } \\
\text { eğitimi almamış olmasına rağmen derse } \\
\text { ilgi duyanların oranını yüksek olduğu } \\
\text { tespit edilmiştir. Ayrı öğrenciler, sadece } \\
\text { okulda aldıkları muhasebe dersinin iş } \\
\text { hayatında çok fazla yeterli olmayacağı } \\
\text { görüšünde oldukları belirlenmiştir. Yine } \\
\text { muhasebe derslerinin işlenmesinde aktif } \\
\text { olarak kalem ve tahta kullanımı beklentisi } \\
\text { yanında teknolojinin de kullanılmasının } \\
\text { istendiğg tespit edilmiştir. Son olarak } \\
\text { öğrencilerin genel anlamda muhasebe } \\
\text { derslerini algilamakta zorlandıkları } \\
\text { belirtilmektedir. Fakat öğrencilerin sadece } \\
\text { sinav zamanlarında muhasebe çalıştıkları } \\
\text { tespit edilmiştir. }\end{array}$ \\
\hline
\end{tabular}




\begin{tabular}{|c|c|c|c|}
\hline 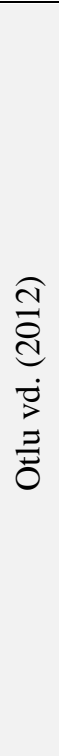 & 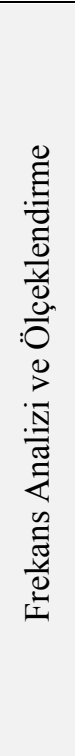 & $\begin{array}{l}\text { Çalışmanın amacı, } \\
\text { yüksekokullarındaki muhasebe ve vergi } \\
\text { bölümü öğrencilerinin bu program ile } \\
\text { ilgili düşünce ve beklentileri ile } 3568 \\
\text { Sayllı yasada meydana gelen } \\
\text { değişikliklerle ilgili bilgi seviyelerini } \\
\text { belirlemektir. Bu kapsamda, 2010-2011 } \\
\text { Bahar yarııllında Malatya Meslek } \\
\text { Yüksekokulu Muhasebe ve Vergi } \\
\text { Uygulamaları Bölümü’nde öğrenim gören } \\
252 \text { öğrenciye anket uygulanmıştır. }\end{array}$ & $\begin{array}{l}\text { Çalışmanın sonucunda, öğrencilerin } \\
\text { tercihlerinde etkili olan önemli bir } \\
\text { unsurunda muhasebe mesleğinin geçerli ve } \\
\text { geleceği olan bir meslek olduğu tespit } \\
\text { edilmiştir. Ancak } 3568 \text { sayıll meslek } \\
\text { yasasını incelememeleri, tercih öncesi } \\
\text { konuyla ilgili doğru rehberlik hizmeti } \\
\text { almamaları sonucu yaplan tercihin birçok } \\
\text { öğrencide konuyu öğrendikten sonra ciddi } \\
\text { pişmanlı yarattı̆̆, bilmeleri halinde } \\
\text { kesinlikle tercih etmeyeceklerini } \\
\text { bildirmeleri şeklinde tespit edilmiştir. } \\
\text { Araştırmada çıan diğer sonuçlar; } \\
\text { öğrencilerin bölümlerindeki teorik ve } \\
\text { uygulamalı eğitim seviyesinin yetersiz } \\
\text { olduğu, fiziki, teknik ve sosyal } \\
\text { imkânlardan memnun olmadıkları, öğretim } \\
\text { üyeleri ile iletişimlerinden memnun } \\
\text { olmadıkları seklinde tespit edilmistir. }\end{array}$ \\
\hline 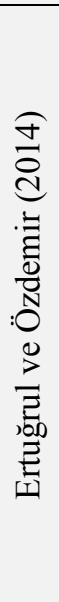 & 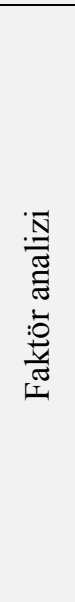 & $\begin{array}{l}\text { Çalşsmanın amac1, Ege Bölgesi'nde } \\
\text { bulunan 9 üniversitede bulunan } 35 \\
\text { Meslek Yüksekokulu ve İktisadi Bilimler } \\
\text { Fakülte'sinde muhasebe dersi alan ön } \\
\text { lisans ve lisans öğrencilerinin (821 } \\
\text { öğrenci) derse yönelik tutumlarının } \\
\text { tespitidir. }\end{array}$ & $\begin{array}{l}\text { Çalışmanın sonucunda, öğrencilerin } \\
\text { muhasebe derslerine karşı tutumlarının } \\
\text { "Gereksiz, S1kıcı ve Angarya", "İstek ve } \\
\text { Arzu", "Gereklilik", "İsteksizlik" ve } \\
\text { "Amaçsızllk" olarak beş grupta } \\
\text { toplanmıştır. Faktör analizinde olumlu } \\
\text { faktörlerin(İstekli ve Arzulu - Gereklilik) } \\
\text { varyansı açıklama oranı \% 23,22 iken, } \\
\text { olumsuz faktörlerin(Gereksiz, S1kıcı ve } \\
\text { Angarya - İsteksizlik - Amaçsızlık) } \\
\text { varyansı açılama oranı \% 29,34 olarak } \\
\text { gerçekleşmiştir. Bu durum öğrencilerin } \\
\text { muhasebe derslerine karşı tutumlarının } \\
\text { olumsuza daha yakı olduğunu } \\
\text { göstermektedir. }\end{array}$ \\
\hline 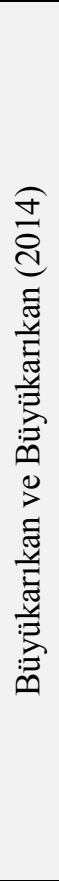 & 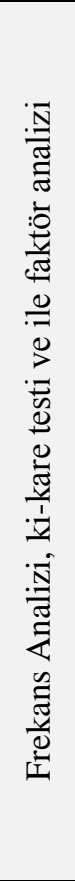 & $\begin{array}{l}\text { Çalışmanın amacı, lisans düzeyinde } \\
\text { muhasebe eğitimi alan ögrencilerin } \\
\text { muhasebe derslerine ve bu derslerin } \\
\text { işlenmesine yönelik tutumlarını tespit } \\
\text { etmektir. Bu kapsamda çalışmada; 2013- } \\
2014 \text { eğitim öğretim yllında Süleyman } \\
\text { Demirel Üniversitesi Yalvaç Büyükkutlu } \\
\text { Uygulamalı Bilimler Yüksek Okulu, } \\
\text { Muhasebe ve Finansal Yönetim } \\
\text { Bölümü'ndeki } 290 \text { öğrenci ana kitleyi } \\
\text { oluşturmaktadır. }\end{array}$ & 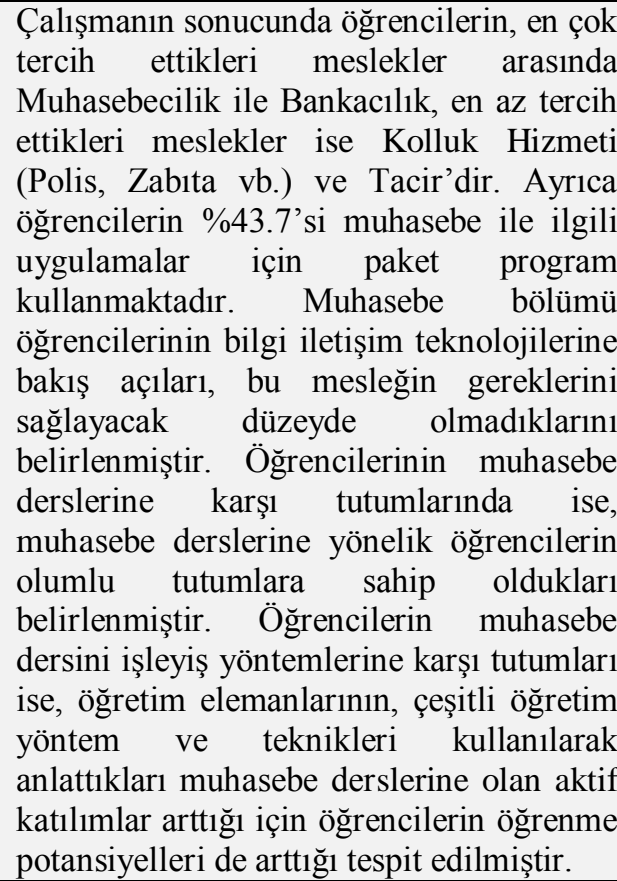 \\
\hline
\end{tabular}




\begin{tabular}{|c|c|c|c|}
\hline 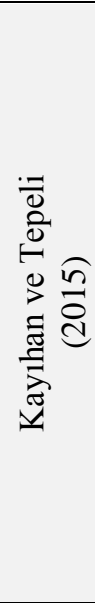 & 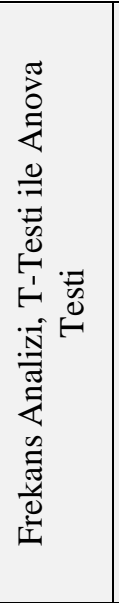 & $\begin{array}{l}\text { Çalışmanın temel amacı, Muğla Sitkı } \\
\text { Koçman Üniversitesi'ne bağlı meslek } \\
\text { yüksekokullarında yer alan Muhasebe ve } \\
\text { Vergi bölüm'lerindeki muhasebe } \\
\text { eğitiminin değerlendirilmesi ve verilen } \\
\text { muhasebe eğitimi açısından Muğla Sitkı } \\
\text { Koçman Üniversitesi’ne bağlı muhasebe } \\
\text { ve vergi bölümü olan meslek } \\
\text { yüksekokullarının karşlaştırılmasıdır. } \\
\text { Çalışmanın kapsamını 2014-2015 eğitim } \\
\text { öğretim yılında Muğla Sitkı Koçman } \\
\text { Üniversitesi'ne bağlı } \\
\text { yüksekokullarında yer alan Muhasebe ve } \\
\text { Vergi bölüm'lerindeki } 350 \text { öğrenci } \\
\text { oluşturmaktadır. }\end{array}$ & $\begin{array}{l}\text { Çalışmanın sonuçlarına göre, muhasebe } \\
\text { ve vergi bölümü ögrencilerinin aldıkları } \\
\text { muhasebe eğitimini değerlendirmede, } \\
\text { öğretim elemanı, derslerin işlenmesi, } \\
\text { bölüm olanakları, plan ve okul dışı } \\
\text { uygulama, ders materyali ve destekleyici } \\
\text { faaliyetler olmak üzere altı faktör } \\
\text { belirlenmiştir. Muhasebe eğitiminin } \\
\text { değerlendirilmesine yardımcı olan bu } \\
\text { faktörlerin meslek yüksekokullarına göre } \\
\text { farklılık gösterdiği saptanmıştır. Ayrıa } \\
\text { söz konusu faktörler incelendiğinde, } \\
\text { verilen muhasebe eğitimini etkileyen en } \\
\text { önemli faktör öğretim elemanıken en az } \\
\text { önemli faktör destekleyici faaliyetlerdir. }\end{array}$ \\
\hline 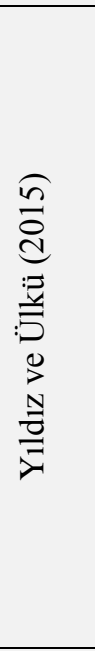 & 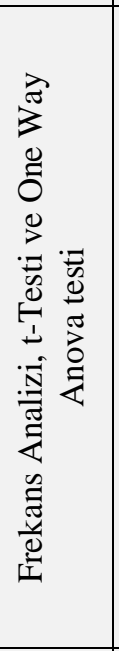 & $\begin{array}{l}\text { Çalışmanın amacı, Sakarya Üniversitesi } \\
\text { İşletme Fakültesi İşletme Bölümü'nde } \\
\text { 2013-2014 eğitim-öğretim yılında lisans } \\
\text { düzeyinde öğrenim gören } 237 \text { işletme } \\
\text { bölümü öğrencilerinin temel muhasebe } \\
\text { dersleri öğrenim kazanımlarına ilişkin } \\
\text { görüşlerinin belirlenmesi ve söz konusu } \\
\text { kazanımlar ile demografik özellikler ve } \\
\text { muhasebe mesleğine ilgi gibi bazı } \\
\text { değişkenler arasındaki ilişkinin tespitidir. }\end{array}$ & $\begin{array}{l}\text { Çalışmanın sonucunda, Genel Muhasebe } \\
\text { Dersi için öğrencilerin; genel olarak } \\
\text { hesapları tanıma ve dönem içi muhasebe } \\
\text { işlemlerini yapabilme açısından kendine } \\
\text { güvendiğini, ancak özellikle bilanço ve } \\
\text { gelir tablosunu düzenlemede ve } \\
\text { dönemsonu mali yapı ile kar/zarar } \\
\text { ilişkisini anlamada sorun yaşadığ tespit } \\
\text { edilmiştir. Ayrıca öğrencilerin muhasebe } \\
\text { dersleri öğrenim kazanımlarına ilişkin } \\
\text { düşünceleri; cinsiyet, öğretim türü, } \\
\text { muhasebe alanında iş tecrübesi olmas, } \\
\text { ailede meslek mensubu varlığı, mezuniyet } \\
\text { sonrası muhasebe mesleğini icra etme } \\
\text { değişkenlerine bağlı olarak farklılaştığ } \\
\text { tespit edilmiştir. }\end{array}$ \\
\hline 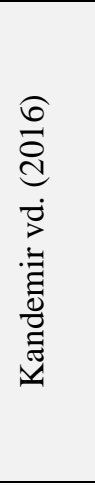 & 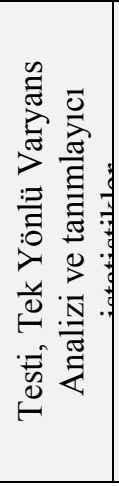 & $\begin{array}{l}\text { Çalışmanın amacı, Afyon Kocatepe } \\
\text { Ünniversitesi Bolvadin, Bayat, Çay ve } \\
\text { Şuhut ilçelerinde bulunan Meslek } \\
\text { Yüksekokullarında muhasebe eğitimi } \\
\text { almakta olan ve almış olan } 272 \\
\text { öğrencinin demografik yapılarının } \\
\text { belirlenerek, muhasebe dersine karşı } \\
\text { bakış açılarının değerlendirilmesidir. }\end{array}$ & $\begin{array}{l}\text { Çalışmanın sonucunda, öğrencilerin } \\
\text { muhasebeye bakış açılarının \%52'sinin } \\
\text { olumlu, \%24'ünün kararsız ve \%24'ünün } \\
\text { de olumsuz olduğu görülmüştür. Ayrıca } \\
\text { öğrencilerin cinsiyeti ile muhasebeyi } \\
\text { öğrenmek iş imkânlarımı artırır sorusu } \\
\text { arasında anlamlı bir ilişki olduğu sonucuna } \\
\text { varılmıştır. Son olarak bölümler arasında } \\
\text { muhasebeye en çok ilgili olanlar sırasıyla } \\
\text { muhasebe ve vergi uygulamaları, dış } \\
\text { ticaret ve işletme bölümü öğrencileri } \\
\text { olduğu sonucuna ulaşılmıştır. }\end{array}$ \\
\hline
\end{tabular}




\begin{tabular}{|c|c|c|c|}
\hline 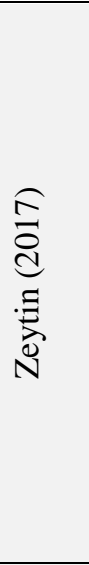 & 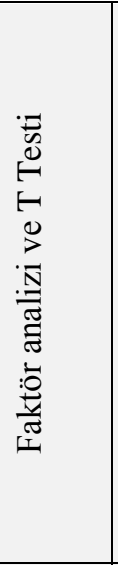 & $\begin{array}{l}\text { Calışmanın amacı, Bilecik Şeyh Edebali } \\
\text { Üniversitesi İ̈BF İşletme Bölümü 2015- } \\
2016 \text { eğitim-öğretim yılında öğrenim } \\
\text { gören } 187 \text { son snnıf öğrencilerinin } \\
\text { muhasebe derslerindeki başarı ve } \\
\text { başarısızlıklarını etkileyen faktörler ile } \\
\text { öğretim elemanından beklentilerini } \\
\text { belirlemektir. }\end{array}$ & $\begin{array}{l}\text { Çalışmanın sonucunda, muhasebe } \\
\text { derslerinde başarıllı olmalarını sağlayan } \\
\text { faktörler incelendiğinde "aileme karşı olan } \\
\text { sorumluluklarım derslerdeki başarımı } \\
\text { etkilemektedir" önermesi en yüksek } \\
\text { ortalamaya sahip önerme olmuştur. Bu } \\
\text { önermeyi "İyi bir çalışma ortamımın } \\
\text { olması derslerdeki başarımı olumlu } \\
\text { etkilemektedir" önermesi ve daha sonra da } \\
\text { "Öğretim elemanını derslere hâkimiyeti } \\
\text { ve öğretme kabiliyeti başarımı olumlu } \\
\text { etkilemektedir" önermesi en yüksek } \\
\text { katıllyorum cevabı alan önermeler olduğu } \\
\text { tespit edilmiştir. }\end{array}$ \\
\hline 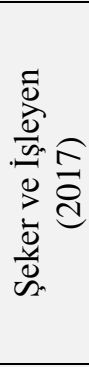 & 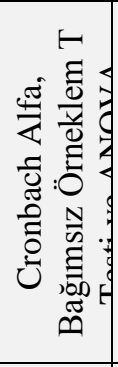 & $\begin{array}{l}\text { Çalışmanın amacı, Hitit Üniversitesi } \\
\text { İïBF' de } 2016 \text { bahar eğitim öğretim } \\
\text { döneminde farklı bölümlerde Genel } \\
\text { Muhasebe dersini alan toplam } 644 \\
\text { öğrencinin muhasebe derslerine karş1 } \\
\text { tutumlarının belirlenmesidir. Bu amaçla } \\
\text { öğrencilerin muhasebe derslerine karş1 } \\
\text { tutumları; bilişsel, duyuşsal ve } \\
\text { davranışsal boyutta incelenmiştir. }\end{array}$ & $\begin{array}{l}\text { Çalışmanın sonuçlarına göre, muhasebe } \\
\text { dersine karşı tutumlar öğrencilerin } \\
\text { bölümleri muhasebe derslerinden } \\
\text { memnuniyet düzeyleri, muhasebe } \\
\text { mesleğini seçme ihtimali, derse çalı̧ma } \\
\text { sebepleri ve dersi alma sayıları } \\
\text { değişkenleri bakımından anlamlı farklılık } \\
\text { gösterdiği tespit edilmiştir. }\end{array}$ \\
\hline 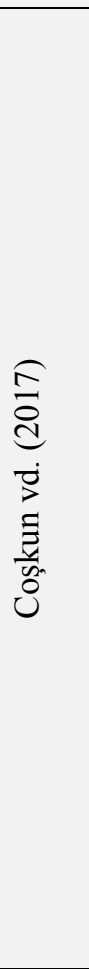 & 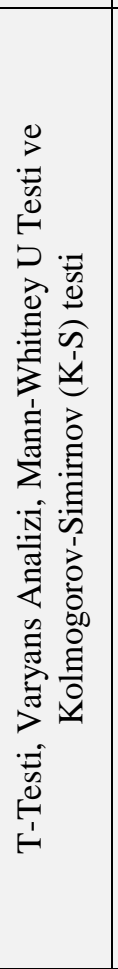 & $\begin{array}{l}\text { Çalış̧manın temel amacı, Manisa Celal } \\
\text { Bayar Üniversitesine bağlı Ahmetli } \\
\text { Meslek Yüksekokulu'nun muhasebe ve } \\
\text { vergi uygulamaları bölümünde öğrenim } \\
\text { gören } 276 \text { öğrencinin mesleki eğitimden } \\
\text { beklentileri ve muhasebe eğitimine ilişkin } \\
\text { görüşlerini tespit etmektir. }\end{array}$ & 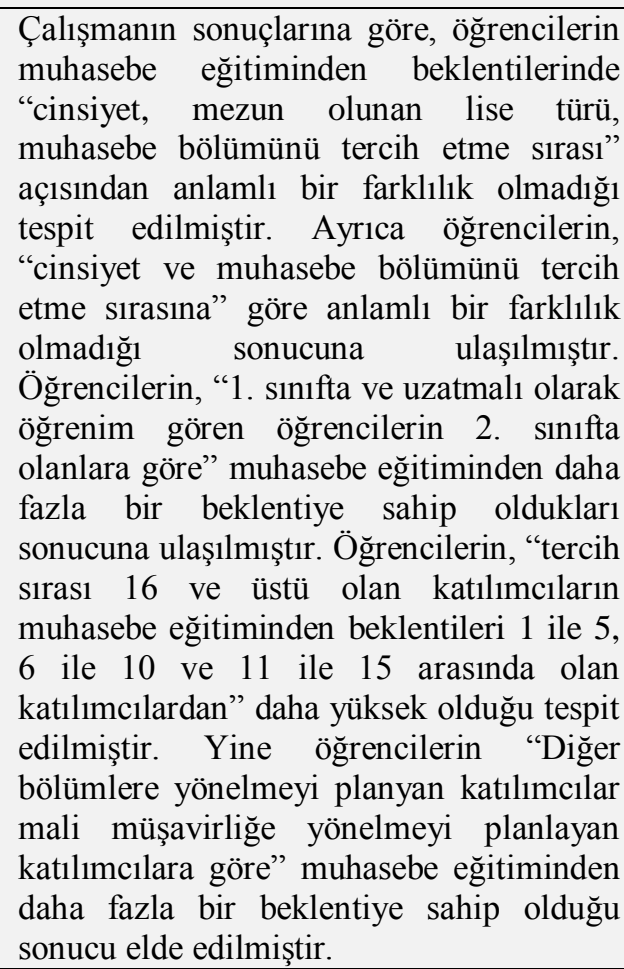 \\
\hline
\end{tabular}




\begin{tabular}{|c|c|c|c|}
\hline 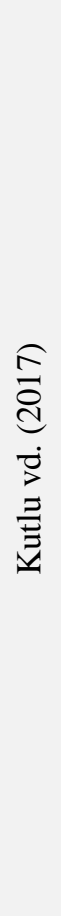 & 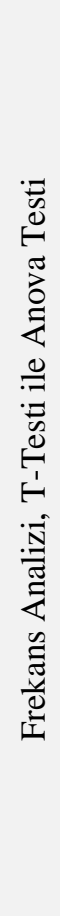 & $\begin{array}{l}\text { Çalışmanın temel amacı, öğrencilerin } \\
\text { muhasebe derslerinin işlenişine ve } \\
\text { muhasebe eğitiminde genelde uygulanan } \\
\text { ölçme-değerlendirme yöntemlerine dair } \\
\text { görüşlerini tespit etme amacına } \\
\text { yöneliktir. Araştırmanın kapsamını 2015- } \\
2016 \text { eğitim öğretim yılında Kafkas } \\
\text { Üniversitesi İktisadi ve İdari Bilimler } \\
\text { Fakültesi ile üniversiteye bağlı Meslek } \\
\text { Yüksekokullarında (MYO) muhasebe } \\
\text { dersi alan } 317 \text { öğrenci oluşturmaktadır. }\end{array}$ & $\begin{array}{l}\text { Çalışmanın sonucunda, araştırmaya katılan } \\
\text { öğrencilerin büyük çoğunluğu üniversite } \\
\text { öncesinde muhasebe altyapısına sahip } \\
\text { değildirler. Yine bu öğrencilerin yarıya } \\
\text { yakın kısmının gelecekte muhasebeci olma } \\
\text { isteğine sahip oldukları görülmüştür. } \\
\text { Sonuçlar genel olarak } \\
\text { değerlendirildiğinde; öğrencilerin } \\
\text { cinsiyeti, öğrenim türü, öğrenim düzeyi, } \\
\text { mezun oldukları lise türü ve üniversiteden } \\
\text { önce muhasebe alt yapısına sahip olup } \\
\text { olmama durumları muhasebe dersleriyle } \\
\text { ilgili düşüncelerini A etkilediği } \\
\text { belirlenmiştir. Ayrıca araştırmaya katılan } \\
\text { öğrencilerin sınıf dışında çok daha fazla } \\
\text { uygulama yapılması gerektiğini, teorik } \\
\text { bilginin yeterli olduğu ancak uygulamada } \\
\text { sorunlar yaşandığını, derslerin slayt } \\
\text { sunumları şeklinde anlatılmasının daha } \\
\text { faydalı olacağını, dersler işlenirken farklı } \\
\text { öğretim teknikleri kullanılırsa dersin } \\
\text { sikıcılığının azda olsa azalacağını } \\
\text { belirtmişlerdir. }\end{array}$ \\
\hline
\end{tabular}

\section{LISANS DÜZEYINDE MUHASEBE EĞİTIMİ ALAN ÖĞRENCİLERDE STRESE NEDEN OLAN FAKTÖRLERLE DERSE YÖNELIK TUTUMLARI ARASINDAKI İLISSTKINIIN ARAŞTIRILMASI}

$\mathrm{Bu}$ bölümde, araştırmanın amacı, önemi, yöntemi, hipotezleri, araştırma sonucunda elde edilen verilerin istatistiksel analizleri sonucu elde edilen bilgilerin sunulmasi ve yorumlanmasından oluşmaktadır.

\subsection{Araştırmanın Amacı ve Önemi}

Öğrencilerin muhasebe eğitimine yönelik tutumlar1 ile strese neden olan faktörler arasındaki ilişkinin araştırılması mesleğin geleceği ve muhasebe eğitimi açısından çok önemlidir. Bu bağlamda çalışmanın amacı, Çankırı Karatekin Üniversitesi İ̈BF'de muhasebe eğitimi alan öğrencilerde strese neden olan faktörlerle derse yönelik tutumları arasındaki ilişkinin araştırılması ve bu ilişkinin demografik değişkenlerle birlikte değerlendirmektir. Bu yolla öğrencilerin strese neden olan faktörleri tespit ederek gerekli önlemler alınabilecektir.

\subsection{Araştırmanın Kapsamı ve Yöntemi}

Muhasebe eğitimi alan öğrencilerde strese neden olan faktörlerle derse yönelik tutumları arasındaki ilişkiyi tespit amacıyla veri toplamak için anket yöntemi kullanılmıştır. Ankette yer alan ifadeler Otlu vd. (2012); Büyükarıkan ve Büyükarıkan (2014), Aşçı vd. (2015) ve Kutlu vd. (2017) tarafindan yapılan çalışmalardan uyarlanarak hazırlanmıştır. Anket, öğrencilerin demografik yapılarının belirlenmesi ve öğrencilerde strese neden olan 
faktörler ile muhasebe derslerine bakış açılarının bunlar arasındaki ilişkilerin belirlenmesine yönelik üç bölümden oluşmakta ve toplam 43 soru yer almaktadır. Birinci bölüm, öğrencilerin demografik özelliklerini belirlemeye yönelik olup, 8 sorudan oluşmaktadır. İkinci bölüm, öğrencilerin genel olarak muhasebe dersine yönelik tutumlarını belirlemeye yönelik olup, 24 sorudan oluşmaktadır. Üçüncü ve son bölümü ise muhasebe eğitimi alan öğrencilerde strese neden olan faktörleri belirlemeye yönelik olup 11 sorudan oluşmaktadır. Ankette yer alan sorular beşli Likert ölçeğine ( $1=$ Kesinlikle katılmıyorum, $2=$ katılmıyorum, $3=$ kararsızım, 4=katılıyorum, $5=$ kesinlikle katılıyorum) katılım derecelerine göre hazırlanmıştır. Elde edilen veriler "SPSS 21.0" istatistik paket programı kullanılarak test edilmiş ve elde edilen bulgular açıklanmıştır.

Araştırmanın evrenini Çankırı Karatekin Üniversitesi İ̈BF 2017-2018 eğitim ve öğretim dönemi bahar yarıyılında eğitim gören İşletme, İktisat, Bankacılık ve Finans ile Uluslararası Ticaret bölümü öğrencileri oluşturmaktadır. Bu öğrencilerin tümüne ulaşmak mümkün olmadığından, kolayda örnekleme yöntemi ile belirlenen örnekleme erişilerek yüz yüze uygulanmış ve 238 adet geçerli anket toplanmıştır. Çalışmada öğrencilerin ifadelere verdikleri yantllar; Frekans analizi, t testleri ve tek yönlü varyans analizi, korelasyon ve regresyon analizleri kullanılarak analiz edilmiştir.

Çalışmada öncelikle pilot uygulama gerçekleştirilmiş anketin uygun olduğuna kanaat getirildiğinde uygulamaya geçilmiştir. Bu kapsamda araştırmada, öncelikle demografik faktörler için frekans analizi yapılmış ve öğrencilerin strese neden olan faktörlerin ortalamaları saptanarak, bu faktörlerin öğrencilerde muhasebe derslerine yönelik tutumlarına etkileri belirlenmeye çalışılmıştır. Bu bağlamda muhasebe eğitimine yönelik tutumlara ve strese neden olan faktörlere ilişkin görüşleri ölçen 35 ifadeyi tek tek analiz etmek karmaşık ve gereksiz olacağından ifadeler faktör analizine tabii tutulmuştur. Faktör analizinde dört ifade belirli bir faktöre gerektiği gibi ait olamadığından analiz dışında bırakılmıştır. Bu nedenle faktör sayısı dörde düşürülmüş ve bu yeni faktörlere Anova ve bağımsız örneklem t-testi uygulanmıştır. $\mathrm{Bu}$ analizlerle demografik özelliklere göre faktörlerde anlamlı farklılı̆ıın bulunup bulunmadığı test edilmiştir.

\subsection{Araştırmanın Hipotezleri}

\section{Dersin Hocasına Yönelik Tutum ile Derse Yönelik Tutum Arasındaki İlişkisi}

Özgüngör (2013) yaptı̆̆ı çalışmada sınıf büyüklüğünün, öğretmenlerin toplam öğrenci sayısının, iş yüklerinin, deneyimlerinin, öğrencilerin öğretim elemanlarına yönelik tutumlarını etkilediğini tespit etmiştir. Lvin, Davies ve Carr (2010), yaptıkları çalı̧̧mada eğitmenin kıyafetlerinin öğrencilerin eğitmenlere karşı tutumlarını ve güvenlerini nasıl etkilediğini araştırmışlardır. Çalı̧̧a sonucunda eğitmenlerin kredibilitesinin, öğrencilerin dersleri başarmaya yönelik çabaları ve diğer davranış değişkenleri ile anlamlı ve pozitif ilişkisi olduğunu bulmuşlardır. Özellikle, eğitmenin kredibilitesi, öğrencinin derse yönelik hazırlıkları, eğiticilerin çabalarının takdir edilmesi, eğitmene olan saygı üzerinde en fazla etkiye sahip unsur olmuştur. Latif ve Miles (2011), çok sayıda uluslararası öğrenciye sahip bir üniversitede ekonomi öğrencilerinin, çeşitli öğretim özelliklerine ve öğretim uygulamalarına nasıl değer verdiklerini değerlendirmişlerdir. Öğrencilerin, etkili bir eğitmenin en önemli 
özelliklerini kendi bilgisi, bilgilerini net bir şekilde açıklayabilme yeteneği ve yeterli hazırlığının olması şeklinde sıraladıklarını tespit etmişlerdir. Hamid ve Zaidatol (2004), işletme öğrencilerinin öğretim ve öğrenimin etkililiğine ilişkin tutumlarını incelemek amacıyla bir çalışma yapmışlardır. Araştırmaya, Malezya'daki üç devlet üniversitesinden yaklaşık 1552 öğrenci katılmıştır. Çalışma sonucunda öğrencilerin eğitmen, öğretim tekniği ve ders faktörlerine yönelik tutumlarında cinsiyet, etnik köken ve akademik başarı puanlarına göre anlamlı farklılıklar gözlenmiştir. Shah (2009), eğitmen davranışının üniversite öğrencilerinin akademik başarıları üzerindeki etkisini araştırmıştır. Öğrencilerin eğitmenlerinin olumlu davranışlarından memnun oldukları ve bu davranışların öğrencilerin akademik başarıları ile oldukça pozitif ve anlamlı bir ilişki içerisinde olduğu ortaya konulmuştur.

\section{H1: Dersin hocasina yönelik tutum derse yönelik tutumu etkilemektedir}

\section{Stres ve Derse Yönelik Öğrenci Bakış Açısı ve Başarısına Etkisi}

Mevcut araştırmalar, stresin öğrenci yaşam kalitesi, üniversite başarısı ve derslere bakış açıları üzerinde olumsuz bir etkisi olduğunu göstermektedir. Literatürde stres ve öğrencilerin üniversite yaşamları ve başarıları üzerine etkisi konusunu ele alan çok sayıda çalışma bulmak mümkündür. $\mathrm{Bu}$ çalışmalardan konumuzla daha fazla ilgili olduğunu düşündüğümüz çalışmaların bir kısmı aşağıda özetlenmiştir

Cahir ve Morris (1991), lisansüstü psikoloji eğitiminde stres faktörlerini araştırmışlardır. Çalışmalarında Psikoloji Öğrenci Stres Anketi (PSSQ) geliştirmişler ve bu anket ile topladıkları veriler üzerinden lisansüstü psikoloji eğitiminin duygusal, finansal ve akademik stres faktörlerinin öğrenciler üzerindeki etkisini araştırmışlardır. Çalışmalarının sonucunda kı öğrencilerin erkeklere göre daha yüksek stres puanlarına sahip olduklarını tespit etmişlerdir. McEwan ve Goldenberg (1999), Kanada' da 3 üniversitede yüksek lisans seviyesinde eğitim gören hemşirelik öğrencilerinin akademik başarılarına, başarı motivasyonunun ve kaygısının etkisini araştırmışlardır. Çalışma sonucunda durumsal kaygı akademik başarı ile negatif korelasyondayken, sürekli kaygı akademik başarının tek geçerli öngörücüsü olmuştur. Brougham ve diğerleri (2009), 166 üniversite öğrencisinin stres faktörlerini (akademisyenler, maddi durum, aile, sosyal etkiler ve günlük hayatın zorlukları) ve stres ile baş etme stratejilerini (kendi kendine yardım, yaklaşım, konaklama, kaçınma ve kendini cezalandırma) incelemişlerdir. Çalışmalarının bulgularına göre, kadın öğrenciler, erkeklerden daha yüksek genel stres düzeyine sahiptirler. Ayrıca kadınlar duygu odaklı stresle baş etme stratejilerini daha fazla kullandıklarını tespit etmişlerdir. How, Shinde ve Willems (2013), muhasebe bölümü öğrencilerinin akademik stresini ölçmeyi amaçlayan bir çalışma yapmışlardır. Çalışma, muhasebe öğrencilerinin akademik stresini ölçen bir ölçeğin geliştirilmesini konu almaktadır. Amerika Birleşik Devletleri'nde 59 muhasebe öğrencisinden topladıkları veriler üzerinden yapılan istatistiksel analizler, aracın muhasebe öğrencilerinin akademik stresinin güvenilir ve geçerli bir ölçeği olduğunu göstermiştir. Stresin kadınlarda erkeklere göre daha yüksek olduğunu tespit etmişlerdir. Aynı zamanda yaşça biraz daha genç öğrencilerde diğerlerine göre daha yüksektir. Misra, McKean, West ve Russo (2000), Amerikalı ve uluslararası öğrencilerin akademik stres düzeylerini araştırmışlardır. Amerikalı öğrencilerin, uluslararası öğrencilere göre daha yüksek stres seviyesine sahip olduklarını bulmuşlardır. Abouserie (1994), üniversite öğrencilerinde stres kaynă̆ını ve düzeyini kontrol odağı ve benlik saygısı ilişkisi bakımından araştırmıştır. Araştırma örneklemi, 675 (202 erkek 
ve 473 kadın) ikinci sınıf lisans öğrencisinden oluşmaktadır. Sonuçlar, sınavların ve sonuçlarının öğrencilerin en yüksek stres nedenleri olduğunu tespit etmişlerdir. Bulgular aynı zamanda k1z öğrencilerin erkeklerden daha fazla stresli olduğunu göstermiştir. Sonuçlar ayrıca, kontrol odağı ile akademik stres arasında pozitif yönde anlamlı bir ilişki olduğunu göstermiştir. Aşçı, Hazar, Kılıç ve Korkmaz (2015), üniversite öğrencilerinde stres nedenlerinin ve stresle başa çıkma biçimlerinin belirlenmesi amacıyla yaptıkları çalışmada kız öğrencilerin sosyal destek boyutundan aldıkları puanlar erkek öğrencilere göre, lisansüstü eğitim almak isteyenlerin problem odaklı başa çıkma puanları lisansüstü eğitim almak istemeyenlere göre daha yüksek bulmuşlardır. Araştırmacılar çalışmada ilişkilerin çıkara dayanmasını, öğretim elemanlarının öğrenciler arasında ayrım yapmasını ve derslerin yoğunluğunu öğrenciler arasında strese neden olan ilk üç faktör olarak belirlemişlerdir. Robotham (2008) çalışmasında, yükseköğretimde okuyan öğrencilerin yaşadığı stresle ilgili önceki araştırmaları incelemiştir. Son 25 yılda yapılan çalışmaları incelediği çalışmasının sonuçlarına göre üniversite öğrencilerinin stres düzeylerindeki artışın sadece Birleşik Krallık ile sınırlı kalmadığını diğer ülkelerde yapılan çalışmalarda da benzer sonuçların bulunduğunu ifade etmiştir. Gabre ve Kumar (2012), algılanan stresin muhasebe öğrencilerinin akademik performansı üzerindeki etkilerini araştırdıkları çalışmalarında kız öğrencilerin erkek öğrencilerden daha yüksek stres düzeyine sahip olduklarını bulmuşlardır. Ayrıca stresin akademik performansı olumsuz yönde etkilediğini tespit etmişlerdir. Smith, Rosenberg ve Haight (2014), ABD' deki üç üniversiteden 557 işletme ve muhasebe lisans öğrencisi üzerinde Algılanan Stres Ölçeği- 10' u test etmişlerdir. Sonuç olarak kısaca PSS10 olarak adlandırılan ölçeğin kişilerin stres düzeylerinin değerlendirmek için kullanılabileceği sonucuna varmışlardır.

H2: Muhasebe ĕgitimi alan ögrencilerde strese neden olan faktörler ile derse yönelik tutumları arasında istatistiksel açıdan anlamlı bir ilişki vardır.

\section{ANALIZ VE BULGULAR}

Araştırma katılımcılarının demografik özellikleri ve analizler neticesinde elde edilen bulgular aşağıda açıklanmıştır.

\subsection{Demografik Bilgilere İlişkin Bulgular}

Ankete katılan öğrencilerin cinsiyetleri, yaşları, bölümleri, öğrenim durumları, mezun olunan lise türü, alınana muhasebe derslerinin sayıs1, mezuniyet sonrası muhasebe alanında çalışmayı düşüncesi gibi demografik özelliklerin istatiksel sonuçları Tablo 3 'te verilmiştir. 
Tablo 3. Demografik Bilgiler

\begin{tabular}{|c|c|c|c|}
\hline \multicolumn{4}{|c|}{ CINSIYET } \\
\hline & Siklık & \multicolumn{2}{|c|}{ Yüzde } \\
\hline \multirow{3}{*}{$\begin{array}{l}\text { Kadin } \\
\text { Erkek } \\
\text { Toplam }\end{array}$} & 122 & \multicolumn{2}{|c|}{51,3} \\
\hline & 116 & \multicolumn{2}{|c|}{48,7} \\
\hline & 238 & \multicolumn{2}{|c|}{100,0} \\
\hline \multicolumn{4}{|c|}{ YAȘ } \\
\hline \multirow{4}{*}{$\begin{array}{c}17-20 \\
21-24 \\
\text { Toplam }\end{array}$} & Siklik & \multicolumn{2}{|c|}{ Yüzde } \\
\hline & 132 & \multicolumn{2}{|c|}{55,5} \\
\hline & 106 & \multicolumn{2}{|c|}{44,5} \\
\hline & 238 & \multicolumn{2}{|c|}{100,0} \\
\hline \multicolumn{4}{|c|}{ BÖLŬM } \\
\hline & & Siklık & Yüzde \\
\hline \multirow{5}{*}{\multicolumn{2}{|c|}{$\begin{array}{c}\text { İşletme } \\
\text { İktisat } \\
\text { Bankacılik ve Finans } \\
\text { Uluslararası Ticaret } \\
\text { Toplam }\end{array}$}} & 50 & 21,0 \\
\hline & & 64 & 26,9 \\
\hline & & 96 & 40,3 \\
\hline & & 28 & 11,8 \\
\hline & & 238 & 100,0 \\
\hline \multicolumn{4}{|c|}{ ÖĞRETİM TÜRU் } \\
\hline & Siklık & \multicolumn{2}{|c|}{ Yüzde } \\
\hline \multirow{3}{*}{$\begin{array}{c}\text { Nomal } \\
\text { Ikinci } \\
\text { Toplam }\end{array}$} & 150 & \multicolumn{2}{|c|}{63,0} \\
\hline & 88 & \multicolumn{2}{|c|}{37,0} \\
\hline & 238 & & 00,0 \\
\hline & SINIF & & \\
\hline Birinci & 86 & & 36,1 \\
\hline İkinci & 46 & & 19,3 \\
\hline Üçüncü & 73 & & 30,7 \\
\hline Dördüncü & 33 & & 13,9 \\
\hline Toplam & 238 & & 100,0 \\
\hline
\end{tabular}

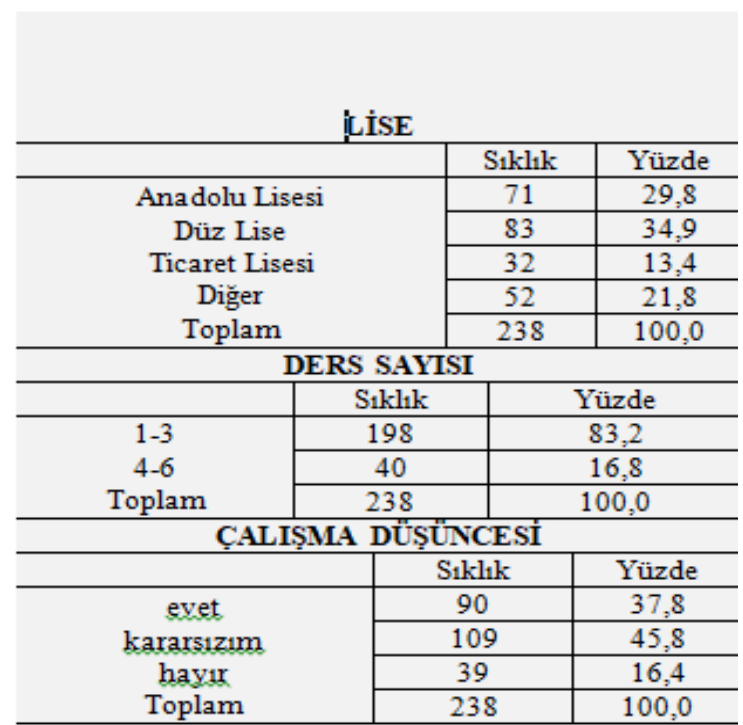

Tablo 3'e göre, araştırmaya katılan öğrencilerin \%51.3'ü kadın, \%48.7'si erkektir. Yine öğrencilerin çoğunlukla bankacılık ve finans bölümü (\%40.3) öğrencisi ve 17-20 yaş aralığında (\%55.5) olduğu, \%63'ü I. öğretim, \%37'si ise II. öğretim öğrencisidir. Öğrencilerin almış oldukları muhasebe derslerinin sayısı 1-3 (\%83,2) arasındadır. Ayrıca araştırmaya katılan öğrencilerin 27,3'ü Anadolu Lisesi, \%34,9'u Düz Lise mezunu olup, dur. Son olarak araştırmaya katılan öğrencilerin çoğunlukla (\%45.8) ileride muhasebe alanında çalışma konusunda kararsız olduğu görülmektedir.

Tablo 4'te ifadelere ait ortalamalar veya öğrencilerin muhasebe derslerine yönelik tutumlarına yönelik cevapları incelediğinde, "Öğretim elemanları muhasebe derslerinde anlatılan konulara yeterince hâkimdirler" ifadesi 4,58 ile en yüksek ortalamaya sahiptir. "Muhasebe dersleriyle ilgili sinavlar ezbere yöneliktir" önermesi ise 2,03 ile en düşük ortalamaya sahip ifadedir. Bu durum öğrencilerin muhasebe dersini veren öğretim üyelerinin bilgilerine güvendiklerini ancak, muhasebe sınavlarının uygulamadan ziyade ezbere yönelik olduğunu düşündüklerini göstermektedir. Ayrıca öğrencilerde strese neden olan faktörler incelendiğinde ise "Mesleğe yönelik iş bulamama kaygım nedeniyle stres yaşamaktayım" ifadesi 3,53 ile en yüksek ortalamaya sahiptir. "Öğretim elemanları öğrenciler arasında ayrım yapması nedeniyle stres yaşamaktayım” önermesi ise 2,17 ile en düşük ortalamaya sahip ifadedir. Bu durum öğrencilerin çoğunlukla gelecekte iş bulma konusunda kaygı yaşadıklarını göstermektedir. Bu bağlamda ders müfredatında mesleki konulara ağırlık verilerek, meslekler hakkında bilgiler verilmesi yararlı olacaktır. Verilerin faktör analizine uygunluğunun test edilmesi için KMO ve Bartlett's testine başvurulmuştur. Tablo 5'te bu testin sonucuna yer verilmiştir. 
Tablo 4. Muhasebe Derslerine Yönelik Tutumlar ve Strese Neden Olan Faktörlere İlişkin İfadelerin Ortalamaları ve Standart Sapmaları

\begin{tabular}{|c|c|c|c|c|}
\hline Faktörler & Sorular & $\mathbf{N}$ & Ortalama & Std. Sapma \\
\hline \multirow{6}{*}{ סُ } & $\begin{array}{l}\text { Öğretim elemanları muhasebe derslerinde anlatılan } \\
\text { konulara yeterince hâkimdirler. }\end{array}$ & 238 & 4,58 &, 779 \\
\hline & $\begin{array}{l}\text { Öğretim elemanları muhasebe derslerine önem } \\
\text { vermekte ve derslere hazırlıklı olarak girmektedirler. }\end{array}$ & 238 & 4,67 & ,626 \\
\hline & $\begin{array}{l}\text { Öğretim elemanları öğrencilerle olan iletişimleri } \\
\text { yeterli veya istenilen düzeydedir. }\end{array}$ & 238 & 4,16 & ,979 \\
\hline & $\begin{array}{l}\text { Ögrretim elemanları muhasebe alanındaki yenilikleri } \\
\text { takip etmekte ve bunları öğrencileriyle } \\
\text { paylaşmaktadırlar. }\end{array}$ & 238 & 4,11 & ,935 \\
\hline & $\begin{array}{l}\text { Öğretim elemanlarına gerektiğinde, ders saatleri } \\
\text { dışında ulaşmak ve bilgi almak mümkündür. }\end{array}$ & 238 & 3,87 & 1,125 \\
\hline & $\begin{array}{l}\text { Derslerden önce muhasebe derslerinin içerikleri } \\
\text { hakkında bilgiler verilmekte ve bir plan oluşturulup } \\
\text { dersler bu plana göre işlenmektedir. }\end{array}$ & 238 & 3,91 & 1,006 \\
\hline \multirow{5}{*}{ 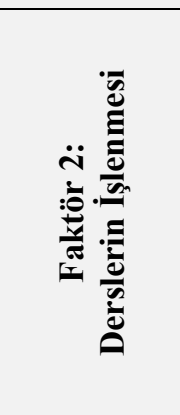 } & $\begin{array}{l}\text { Muhasebe dersleri teorik olarak yeterlidir. Ancak } \\
\text { uygulamada problemler vardır. }\end{array}$ & 238 & 3,35 & 1,369 \\
\hline & $\begin{array}{l}\text { Muhasebe derslerinin işlenişinde farklı öğretim } \\
\text { teknikleri (tahta, tepegöz ve slayt) uygulanmaktadır. }\end{array}$ & 238 & 3,53 & 1,228 \\
\hline & $\begin{array}{l}\text { Muhasebe derslerinin ders saati sayısı, aldığımız } \\
\text { eğitim için yeterlidir. }\end{array}$ & 238 & 3,65 & 1,247 \\
\hline & $\begin{array}{l}\text { Muhasebe derslerinin daha iyi anlaşılması için örnek } \\
\text { olaylara ağırlıklı olarak yer verilmektedir. }\end{array}$ & 238 & 4,19 & ,987 \\
\hline & $\begin{array}{l}\text { Ögretim elemanları muhasebe derslerini monoton } \\
\text { olarak anlatmaktadırlar. }\end{array}$ & 238 & 3,02 & 1,288 \\
\hline \multirow{5}{*}{ 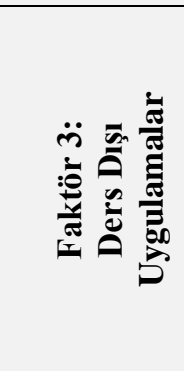 } & Muhasebe dersleri iş hayatında avantaj sağlayacaktır. & 238 & 4,41 & ,932 \\
\hline & $\begin{array}{l}\text { Muhasebe alanındaki gelişmeleri merak edip takip } \\
\text { ediyorum. }\end{array}$ & 238 & 2,99 & 1,238 \\
\hline & $\begin{array}{lcc}\text { Muhasebe dersleri ilgi alanlarımıza } & \text { uygun } & \text { ve } \\
\text { ihtiyaçlarımızı karşlayacak sayı ve çeşitliliktedir. }\end{array}$ & 238 & 3,52 & 1,113 \\
\hline & $\begin{array}{l}\text { Verilen muhasebe dersleri mezuniyet sonrası sınavlar } \\
\text { için yeterlidir. }\end{array}$ & 238 & 3,49 & 1,124 \\
\hline & $\begin{array}{l}\text { İssletmeler ziyaret edilerek uygulamalar yakından } \\
\text { izlenmektedir. }\end{array}$ & 238 & 2,76 & 1,435 \\
\hline \multirow{5}{*}{ 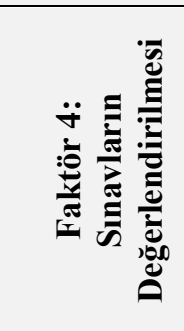 } & $\begin{array}{l}\text { Muhasebe sınav soruları başarımızı ölçecek nitelikte } \\
\text { hazırlanmaktadır. }\end{array}$ & 238 & 3,71 & 1,146 \\
\hline & Muhasebe dersleriyle ilgili sınavlar ezbere yöneliktir. & 238 & 2,03 & 1,098 \\
\hline & Muhasebe derslerinde başarı notu çok yüksektir. & 238 & 2,98 & 1,254 \\
\hline & $\begin{array}{l}\text { Muhasebe derslerinde vize sinavı yerine bireysel } \\
\text { ödevler verilmelidir. }\end{array}$ & 238 & 3,02 & 1,674 \\
\hline & $\begin{array}{l}\text { Muhasebe derslerinde sınavlarla ilgili itirazlarımız } \\
\text { önemsenmektedir. }\end{array}$ & 238 & 3,51 & 1,190 \\
\hline \multirow{3}{*}{ 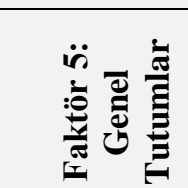 } & Muhasebe derslerini gerçekten seviyorum. & 238 & 3,40 & 1,437 \\
\hline & Muhasebe dersleri günlük hayat için çok gereklidir. & 238 & 3,21 & 1,386 \\
\hline & Muhasebe hakkında daha çok şey öğrenmek isterim & 238 & 3,67 & 1,264 \\
\hline \multirow{2}{*}{ 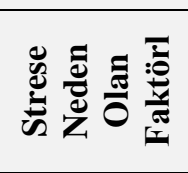 } & $\begin{array}{l}\text { Üniversitede ilişkilerin çıkara dayanması nedeniyle } \\
\text { stres yaşamaktayım }\end{array}$ & 238 & 3,12 & 1,497 \\
\hline & $\begin{array}{l}\text { Üniversitede kendimi yeterince ifade edememe } \\
\text { nedeniyle stres yaşamaktayım }\end{array}$ & 238 & 2,59 & 1,446 \\
\hline
\end{tabular}




\begin{tabular}{|c|c|c|c|}
\hline $\begin{array}{l}\text { Üniversitede bana karşı önyargılı tutum ve davranışlar } \\
\text { nedeniyle stres yaşamaktayım }\end{array}$ & 238 & 2,34 & 1,458 \\
\hline $\begin{array}{l}\text { Öğretim elemanları öğrenciler arasında ayrım yapması } \\
\text { nedeniyle stres yaşamaktayım }\end{array}$ & 238 & 2,17 & 1,425 \\
\hline $\begin{array}{l}\text { Ders konularının yeterince anlaşılmaması nedeniyle } \\
\text { stres yaşamaktayım }\end{array}$ & 238 & 2,72 & 1,501 \\
\hline Derslerin yoğunluğu nedeniyle stres yaşamaktayım & 238 & 3,19 & 1,456 \\
\hline $\begin{array}{l}\text { Mesleğe yönelik iş bulamama kaygım nedeniyle stres } \\
\text { yaşamaktayım }\end{array}$ & 238 & $\mathbf{3 , 5 3}$ & 1,539 \\
\hline $\begin{array}{l}\begin{array}{l}\text { Sinavların ezbere yönelik olması nedeniyle stres } \\
\text { yaşamaktayım }\end{array} \\
\end{array}$ & 238 & 2,63 & 1,423 \\
\hline $\begin{array}{l}\text { Derslerde başarısız olma korkusu nedeniyle stres } \\
\text { yaşamaktayım }\end{array}$ & 238 & 3,42 & 1,467 \\
\hline $\begin{array}{l}\text { Mezuniyet sonrası ne yapacağımı bilememe kaygısı } \\
\text { nedeniyle stres yaşamaktayım }\end{array}$ & 238 & 3,51 & 1,528 \\
\hline $\begin{array}{l}\text { Üniversite hayatımda yaşadığım maddi sıkıntılar } \\
\text { nedeniyle stres yaşamaktayım }\end{array}$ & 238 & 3,02 & 1,451 \\
\hline
\end{tabular}

Tablo 5. KMO ve Barlett's Testi Sonuçları

\begin{tabular}{|l|l|r|}
\hline \multicolumn{2}{|c|}{ KMO and Bartlett's Test (Derse Tutum Faktörü) } \\
\hline KMO Örnek Yeterlilik Ölçüsü. & Yaklaşık Ki-Kare & 0,745 \\
\hline \multirow{2}{*}{ Barlett's Küresellik Testi } & Serbestlik Derecesi & 1299,590 \\
\cline { 2 - 3 } & Anlamlılık & 276 \\
\hline \multicolumn{2}{|c|}{ KMO and Bartlett's Test (Stres Faktörü) } & 0,000 \\
\hline KMO Örnek Yeterlilik Ölçüsü . & Yaklaşık Ki-Kare & 0,839 \\
\hline \multirow{2}{*}{ Barlett's Küresellik Testi } & Serbestlik Derecesi & 957,708 \\
\cline { 2 - 3 } & Anlamlllı & 55 \\
\hline
\end{tabular}

Soru gruplarının faktör analizine uygunluğunu ölçen KMO değerleri ise stres faktörünün ölçeğinin 0,839 , derse tutum faktörü ölçeğinin ise 0,745 çıkmıştır. Faktör analizine uygunluk için bu değerin 0,60'nin üstünde olması yeterli görülmektedir. Ayrıca, Barlett's küresellik testi sonuçlarının anlamlı çıkması da bu veri setinin faktör analizine uygun olduğunu göstermektedir.

Tablo 6. Muhasebe dersine yönelik tutumların ve Stres nedenlerinin Faktör Analizi Özdeğerler ve Varyans Açıklama Yüzdeleri

\begin{tabular}{|c|c|c|c|c|c|c|}
\hline \multirow{2}{*}{$\begin{array}{l}\text { Faktör (F) } \\
\text { Derse } \\
\text { yönelik } \\
\text { tutum }\end{array}$} & \multicolumn{3}{|c|}{$\begin{array}{c}\text { Initial Eigenvalues } \\
\text { (Başlangıç Özdeğerleri) }\end{array}$} & \multicolumn{3}{|c|}{$\begin{array}{l}\text { Rotation Sums of Squared Loadings } \\
\text { (Rotasyon Sonrası Yüzde Yükler) }\end{array}$} \\
\hline & Toplam & $\begin{array}{c}\text { Varyans } \\
\text { Açıklama } \\
\%\end{array}$ & $\underset{\%}{\text { Kümülâtif }}$ & Toplam & $\begin{array}{c}\text { Varyans } \\
\text { Açıklama } \\
\%\end{array}$ & $\underset{\%}{\text { Kümülâtif }}$ \\
\hline 1. $\mathrm{F}$ & 4,235 & 26,471 & 26,471 & 3,094 & 19,338 & 19,338 \\
\hline 2. $\mathrm{F}$ & 2,088 & 13,048 & 39,520 & 2,833 & 17,703 & 37,041 \\
\hline 3. F & 1,519 & 9,494 & 49,014 & 1,688 & 10,550 & 47,591 \\
\hline 4. $\mathrm{F}$ & 1,427 & 8,918 & 57,932 & 1,654 & 10,341 & 57,932 \\
\hline
\end{tabular}




\begin{tabular}{|c|c|c|c|c|c|c|c|c|c|}
\hline \multirow{2}{*}{$\begin{array}{l}\text { Faktör } \\
\text { (F) } \\
\text { Stres } \\
\text { nedenler } \\
\text { i }\end{array}$} & \multicolumn{3}{|c|}{$\begin{array}{c}\text { Initial Eigenvalues } \\
\text { (Başlangıç Özdeğerleri) }\end{array}$} & \multicolumn{3}{|c|}{$\begin{array}{l}\text { Extraction Sums of Squared } \\
\text { Loadings } \\
\text { (Çıkarma Sonrası Yüzde } \\
\text { Yükler) }\end{array}$} & \multicolumn{3}{|c|}{$\begin{array}{l}\text { Rotation Sums of Squared } \\
\text { Loadings } \\
\text { (Rotasyon Sonrası Yüzde } \\
\text { Yükler) }\end{array}$} \\
\hline & $\begin{array}{c}\text { Topla } \\
\text { m }\end{array}$ & $\begin{array}{c}\text { Varyans } \\
\text { Açıklam } \\
\text { a } \\
\%\end{array}$ & $\begin{array}{c}\text { Kümülâti } \\
\mathbf{f} \\
\%\end{array}$ & \begin{tabular}{|c|} 
Topla \\
m
\end{tabular} & $\begin{array}{c}\text { Varyans } \\
\text { Açılam } \\
\mathbf{a} \\
\%\end{array}$ & $\begin{array}{c}\text { Kümülâti } \\
\text { f } \\
\%\end{array}$ & $\begin{array}{c}\text { Topla } \\
\text { m }\end{array}$ & $\begin{array}{l}\text { Varyans } \\
\text { Açılam } \\
\mathbf{a} \\
\%\end{array}$ & $\begin{array}{c}\text { Kümülâti } \\
\text { f } \\
\%\end{array}$ \\
\hline 1. $\mathrm{F}$ & 3,724 & 46,553 & 46,553 & 3,724 & 46,553 & 46,553 & 2,401 & 30,017 & 30,017 \\
\hline 2. $\mathrm{F}$ & 1,040 & 12,995 & 59,548 & 1,040 & 12,995 & 59,548 & 2,362 & 29,531 & 59,548 \\
\hline
\end{tabular}

Tablo 6, öğrencilerin muhasebe derslerine yönelik tutumlarını ve stres nedenlerini değerlendirmek üzere uygulanan faktör analizine ilişkin özdeğer ve varyans açıklama yüzdelerini göstermektedir. Tablo 6 incelendiğinde öğrencilerin muhasebe derslerine yönelik tutumlarıyla ilgili olarak ankette yer alan soruları faktör analizi sonucunda 4 faktör altında toplandığ 1 tespit edilmiştir. Stres ölçeği ise 2 faktör altında toplanmıştır. Öğrencilerin muhasebe derslerine yönelik tutumları ölçeğine ilişkin faktör analizi sonucunda açıklanan varyans \%60' tır. Anti-image korelasyon matrisi tablosuna bakılarak korelasyon değeri 0.50' nin altında olan sorular analizden çıkartılarak faktör analizi tekrar yapılmıştır. Daha sonra döndürülmüş bileşen matrisinde bulunduğu faktörü açıklama gücü 0.50' nin altında olanlar ve birden fazla faktör arasında yer alan maddeler belirlenmiş ve veri setinden çıkartılarak analiz tekrarlanmıştır. Sonuç olarak öğrencilerin muhasebe derslerine yönelik tutumlarını ölçmeyi hedefleyen ankette yer alan maddeler 4 faktör altında toplanmıştır. Söz konusu faktörler Tablo 7 ve 8'de gösterilmiştir.

Tablo 7. Faktör analizi (Muhasebe Derslerine yönelik tutum)

\begin{tabular}{|c|c|c|c|c|}
\hline İfadeler & Faktör1 & Faktör2 & Faktör3 & Faktör4 \\
\hline Muhasebe hakkında daha çok şey öğrenmek isterim & ,833 & , 100 & ,088 &,- 247 \\
\hline Muhasebe dersleri günlük hayat için çok gereklidir. & ,805 & ,077 & 101 &,- 022 \\
\hline Muhasebe derslerini gerçekten seviyorum. & ,790 & 216 & 073 &,- 008 \\
\hline Muhasebe dersleri iş hayatında avantaj sağlayacaktır. &, 580 &, 052 &,- 037 & ,334 \\
\hline $\begin{array}{l}\text { Muhasebe dersleri ilgi alanlarımıza uygun ve ihtiyaçlarımızı karşılayacak } \\
\text { sayı ve çeşitliliktedir. }\end{array}$ & ,546 & 194 &, 178 & ,433 \\
\hline Muhasebe alanındaki gelişmeleri merak edip takip ediyorum. & ,539 &,- 030 & ,064 & 264 \\
\hline $\begin{array}{l}\text { Öğretim elemanları muhasebe derslerine önem vermekte ve derslere } \\
\text { hazırlıklı olarak girmektedirler. }\end{array}$ &,- 077 & ,793 &,- 068 & , 147 \\
\hline $\begin{array}{l}\text { Öğretim elemanları muhasebe derslerinde anlatılan konulara yeterince } \\
\text { hâkimdirler. }\end{array}$ & ,117 & ,722 &,- 190 & ,244 \\
\hline $\begin{array}{l}\text { Öğretim elemanları muhasebe alanındaki yenilikleri takip etmekte ve } \\
\text { bunları öğrencileriyle paylaşmaktadırlar. }\end{array}$ & , 102 & ,720 & , 138 &,- 051 \\
\hline $\begin{array}{l}\text { Öğretim elemanları öğrencilerle olan iletişimleri yeterli veya istenilen } \\
\text { düzeydedir. }\end{array}$ & , 157 & ,673 & , 158 & ,098 \\
\hline $\begin{array}{l}\text { Öğretim elemanlarına gerektiğinde, ders saatleri dışında ulaşmak ve bilgi } \\
\text { almak mümkündür. }\end{array}$ & ,208 & ,625 & ,334 &,- 240 \\
\hline İşletmeler ziyaret edilerek uygulamalar yakından izlenmektedir. &,- 021 & ,099 & ,788 & ,140 \\
\hline Muhasebe derslerinde başarı notu çok yüksektir. &, 149 &,- 080 & ,645 &,- 127 \\
\hline Muhasebe derslerinde sınavlarla ilgili itirazlarımız önemsenmektedir. & 166 & ,364 & ,575 & ,228 \\
\hline
\end{tabular}




\begin{tabular}{|l|r|r|r|r|}
\hline Muhasebe derslerinin ders saati sayısı, aldığımız eğitim için yeterlidir. &,- 050 &,- 024 &, 196 &, 789 \\
\hline $\begin{array}{l}\text { Muhasebe derslerinin daha iyi anlaşılması için örnek olaylara ağırlıklı } \\
\text { olarak yer verilmektedir. }\end{array}$ &, 229 &, 259 &,- 161 &, 602 \\
\hline $\begin{array}{l}\text { Ekstraksiyon Method: Temel Bileşenler Analizi. } \\
\text { Rotasyon Method: Kaiser Normalizasyonlu Varimax }\end{array}$ & & \\
\hline a. 5 öteleme sonucunda ulaşılan rotasyon. & \\
\hline
\end{tabular}

Tablo 8. Faktör analizi (Strese neden olan faktörler)

\begin{tabular}{|c|c|c|}
\hline Iffadeler & Faktör1 & Faktör2 \\
\hline Ders konularının yeterince anlaşılmaması nedeniyle stres yaşamaktayım & ,739 & ,197 \\
\hline Derslerin yoğunluğu nedeniyle stres yaşamaktayım & 699 & ,205 \\
\hline $\begin{array}{l}\text { Üniversitede kendimi yeterince ifade edememe nedeniyle stres } \\
\text { yaşamaktayım }\end{array}$ & ,677 & , 146 \\
\hline Sınavların ezbere yönelik olması nedeniyle stres yaşamaktayım & 653 & ,221 \\
\hline Üniversitede ilişkilerin çıkara dayanması nedeniyle stres yaşamaktayım &, 542 & ,364 \\
\hline $\begin{array}{l}\text { Mezuniyet sonrası ne yapacağımı bilememe kaygısı nedeniyle stres } \\
\text { yaşamaktayım }\end{array}$ & ,214 & ,876 \\
\hline Mesleğe yönelik iş bulamama kaygım nedeniyle stres yaşamaktayım & ,231 & ,829 \\
\hline Derslerde başarısız olma korkusu nedeniyle stres yaşamaktayım & ,295 & ,790 \\
\hline $\begin{array}{l}\text { Ekstraksiyon Method: Temel bileşenler analizi. } \\
\text { Rotasyon Method: Kaiser Normalizasyonlu Varimax }\end{array}$ & & \\
\hline
\end{tabular}

Daha sonra her bir faktörün güvenilirlik analizleri yapılmış ve Cronbach' s Alpha değerleri, birinci faktörün 0.785 , ikinci faktörün 0.713 , üçüncü faktörün 0.540 ve 4 . faktörün 0,507 olarak hesaplanmıştır. 3. ve 4. faktörlerin güvenilirlikleri oldukça düşük olduğundan bu faktörlerin kullanılamayacağına kanaat getirilmiş ve analizler birinci ve ikinci faktörler dikkate alınarak gerçekleştirilmiştir. 11 maddeden oluşan son ölçeğin güvenilirlik analizi sonucu ve Cronbach's Alpha değeri Tablo 9' de görüldüğü gibi \%77,9 bulunmuştur.

Tablo 9. Derse Bakış Açısı Güvenilirlik Analizi

\begin{tabular}{cc}
\hline Cronbach's Alpha & $\mathrm{N}$ \\
\hline 0,779 & 11 \\
\hline
\end{tabular}

Aynı faktör analizi adımları stres ölçeği için de uygulanmıştır. Analiz sonucunda iki faktör ortaya çıkmıştır. Ölçekte yer alan, "Öğretim elemanları öğrenciler arasında ayrım yapması nedeniyle stres yaşamaktayım", "Üniversitede bana karşı önyargılı tutum ve davranışlar nedeniyle stres yaşamaktayım", "Üniversite hayatımda yaşadığım maddi sıkıntılar nedeniyle stres yaşamaktayım" maddeleri birden fazla faktör altında yer alabildiğinden ölçekten çıkartılmış ve faktör analizi tekrarlanmıştır. Açıklanan varyans \%59,638 olmuştur. Oluşan faktörler Tablo 10'da gösterilmiştir. 
Tablo 10. Stres Faktörleri

\title{
FAKTÖR 1: GELECEK KAYGISI
}

\begin{abstract}
Mezuniyet sonrası ne yapacağımı bilememe kaygısı nedeniyle stres yaşamaktayım
Mesleğe yönelik iş bulamama kaygım nedeniyle stres yaşamaktayım

Derslerde başarısız olma korkusu nedeniyle stres yaşamaktayım
\end{abstract}

\section{FAKTÖR 2: SOSYAL ÇEVRE VE DERS FAKTÖRÜ}

Üniversitede kendimi yeterince ifade edememe nedeniyle stres yaşamaktayım

Üniversitede ilişkilerin çıkara dayanması nedeniyle stres yaşamaktayım

Ders konularının yeterince anlaşılmaması nedeniyle stres yaşamaktayım

Derslerin yoğunluğu nedeniyle stres yaşamaktayım

Güvenilirlik analizi sonucunda 7 maddeden oluşan genel ölçek puanının (Cronbach' Alpha) 0,822 olduğu görülmüştür. 1. faktörün $0,841,2$. faktörün 0,705 olduğu görülmüştür. $\mathrm{Bu}$ nedenle tüm faktörlerin analizlerde kullanılabileceğine karar verilmiştir.

\subsection{Korelasyon Analizleri}

İkinci aşamada öğrencilerin muhasebe derslerine yönelik tutumlarına etki eden stres faktörlerinin belirlenmesi amacıyla korelasyon analizleri yapılmıştır. Analiz sonucunda muhasebe derslerine yönelik tutumları etkileyen stres faktörlerinin sosyal çevre ve gelecek kaygısı olduğu görülmüştür. Bununla birlikte öğretim elemanlarına yönelik tutumlar ile derse yönelik tutumlar arasında pozitif ilişkili olduğu bulunmuştur. Yine stres faktörlerinin birbirleriyle yakından ilişkili oldukları görülmüştür. Bu sonuçlar, öğrencilerin dersi anlatan öğretim üyelerine yönelik olumlu düşünceler taşımasının derse karşı daha fazla olumlu bakışa neden olduğunu göstermektedir. Sonuçlar Tablo 11'de verilmiştir.

Tablo 11. Korelasyon Analizi Sonuçları

\begin{tabular}{|c|c|c|c|c|c|}
\hline & & $\begin{array}{c}\text { Tutum 1: } \\
\text { Öğretim } \\
\text { Elemanına } \\
\text { Yönelik Tutum }\end{array}$ & $\begin{array}{l}\text { Tutum 2: } \\
\text { Derse Yönelik } \\
\text { Tutum }\end{array}$ & $\begin{array}{l}\text { Stres 1: } \\
\text { Sosyal } \\
\text { Çevre Ve } \\
\text { Ders }\end{array}$ & $\begin{array}{l}\text { Stres 2: } \\
\text { Gelecek } \\
\text { Kaygısı }\end{array}$ \\
\hline \multirow{3}{*}{$\begin{array}{l}\text { Tutum 1: Öğretim } \\
\text { Elemanına } \\
\text { Tutum }\end{array}$} & $\begin{array}{l}\text { Pearson } \\
\text { Korelasyon }\end{array}$ & 1 & $0,317^{* *}$ & $-0,046$ & 0,022 \\
\hline & $\begin{array}{l}\text { Anlamlılık } \\
\text { (2-yönlü) }\end{array}$ & & 0,000 & 0,482 & 0,741 \\
\hline & $\mathrm{N}$ & 238 & 238 & 238 & 238 \\
\hline \multirow{3}{*}{$\begin{array}{l}\text { Tutum 2: } \\
\text { Yönelik Tutum }\end{array}$} & $\begin{array}{l}\text { Pearson } \\
\text { Korelasyon }\end{array}$ & $0,317^{* *}$ & 1 & $-0,136^{*}$ & $-0,185^{*}$ \\
\hline & $\begin{array}{l}\text { Anlamlilik } \\
\text { (2-yönlü) }\end{array}$ & 0,000 & & 0,036 & 00,015 \\
\hline & $\mathrm{N}$ & 238 & 238 & 238 & 238 \\
\hline \multirow{3}{*}{$\begin{array}{l}\text { Stres 1: Sosyal Çevre } \\
\text { Ve Ders }\end{array}$} & $\begin{array}{l}\text { Pearson } \\
\text { Korelasyon }\end{array}$ & $-0,046$ &,$- 136^{*}$ & 1 & $0,554^{* *}$ \\
\hline & $\begin{array}{l}\text { Anlamlılık } \\
\text { (2-yönlü) }\end{array}$ & 0,482 & 0,036 & & 0,000 \\
\hline & $\mathrm{N}$ & 238 & 238 & 238 & 238 \\
\hline
\end{tabular}




\begin{tabular}{|c|c|c|c|c|c|c|}
\hline \multirow{3}{*}{$\begin{array}{l}\text { Stres 2 } \\
\text { Kaygisı }\end{array}$} & & $\begin{array}{l}\text { Pearson } \\
\text { Korelasyon }\end{array}$ & 0,022 & $-0,140^{*}$ & $0,554^{* *}$ & 1 \\
\hline & Gelecek & $\begin{array}{l}\text { Anlamlılık } \\
\text { (2-yönlü) }\end{array}$ & 0,741 & 0,030 & 0,000 & \\
\hline & & $\mathrm{N}$ & 238 & 238 & 238 & 238 \\
\hline
\end{tabular}

\subsection{Regresyon Analizleri}

Çalışmanın bu bölümünde ise literatürdeki konu ile ilişkili çalışmaların bulgularından hareketle regresyon analizleri gerçekleştirilmiştir. Regresyon analizleri, bir önceki başlık altında sonuçları verilen (Tablo 11) korelasyon analizinin ortaya koyduğu ilişkiler temelinde gerçekleştirilmiştir. Tablo 11'de görüldüğg̈ üzere, muhasebe dersine yönelik tutum ile dersin ögretim elemanına yönelik tutum arasında pozitif ve anlamlı bir ilişki tespit edilmiştir. Dolayısıyla öğrenciler muhasebe derslerini dersin öğretim elemanından bağımsız değerlendirmemektedirler. Buna göre, dersin öğretim elemanına kaşı tutum olumlu ise derse yönelik tutumda da olumludur diyebiliriz. Derse yönelik tutumun bağımlı değişken olarak alındığı bir regresyon analizi sonucu Tablo 12'de gösterilmiştir.

Tablo 12. Derse Yönelik Tutum*Öğretim Elemanına Yönelik Tutum Regresyon Analizi Sonuçları

\begin{tabular}{l|r|r|l|l}
\hline Model & R & R Kare & $\begin{array}{l}\text { Düzeltilmiş R } \\
\text { Kare }\end{array}$ & $\begin{array}{l}\text { Std. Tahmin } \\
\text { Hatası }\end{array}$ \\
\hline 1 &, 318 &, 101 &, 096 & 5,115 \\
\hline
\end{tabular}

\begin{tabular}{|c|c|c|c|c|c|c|}
\hline \multicolumn{7}{|c|}{ Bağımlı Değişken: Tutum 2: Derse Yönelik Tutum Puanı } \\
\hline \multicolumn{7}{|c|}{ ANOVA $^{\mathrm{a}}$} \\
\hline \multicolumn{2}{|c|}{ Model } & Kareler Toplam & $\mathrm{Sd}$ & Kareler & $\mathrm{F}$ & Anlamlılık \\
\hline \multirow{3}{*}{1} & Regression & 501,756 & 1 & 501,756 & 19,175 &, $000^{\mathrm{b}}$ \\
\hline & Residual & 4474,695 & 236 & 26,168 & & \\
\hline & Total & 4976,451 & 237 & & & \\
\hline
\end{tabular}

b. Sabit Değer, Tutum 1: Öğretim Elemanına Yönelik Tutum Puanı

\begin{tabular}{|c|c|c|c|c|c|c|}
\hline \multirow{2}{*}{\multicolumn{2}{|c|}{ Model }} & \multicolumn{2}{|c|}{ Standartlanmamış Katsayılar } & \multirow{2}{*}{\begin{tabular}{|r|}
$\begin{array}{l}\text { Standardize } \\
\text { Katsay } 1\end{array}$ \\
Beta
\end{tabular}} & \multirow[t]{2}{*}{$\mathrm{t}$} & \multirow{2}{*}{$\begin{array}{l}\text { Anlamlılık } \\
\text { Düzeyi } \\
\text { (P) }\end{array}$} \\
\hline & & B & Std. Hata & & & \\
\hline & Sabit & 9,972 & 2,576 & & 3,872 &, 000 \\
\hline 1 & $\begin{array}{l}\text { Tutum 1:Öğretim } \\
\text { Elemanına Yönelik Tutum } \\
\text { Puanı }\end{array}$ &, 521 &, 119 & ,318 & 4,379 & ,000 \\
\hline
\end{tabular}

Regresyon analizi sonuçlarına göre, öğretim elemanına yönelik tutumun derse yönelik tutumu açıklama gücü $\left(\mathrm{R}^{2}\right) \% 10$ ' dur. Sonuçlar anlamlıdır $($ Sig. $<0.05)$. Basit doğrusal regresyon modeli ise aşağıdaki gibidir: 


\section{Derse yönelik Tutum $=9,972+$ Öğretim Elemanma yönelik Tutum $\times 0.521$}

$\mathrm{Bu}$ modele göre öğretim elemanına yönelik tutum puanı 5 maddeden her birine 5 puan verilmesi durumunda 25 ise derse yönelik tutum 22,997 (derse yönelik tutum ölçeğinin tam puan1 30' dur) olacak şekilde tahmin edilebilmektedir.

\section{Derse Yönelik Tutum * Gelecek Kaygısı Stres Faktörü Regresyon Analizi}

Yukarıdaki Tablo 10' da görüldüğü üzere derse yönelik tutum ile gelecek kaygısı stres faktörü arasındaki ilişki negatif ve anlamlıdır. Dolayısıyla öğrencilerin gelecek kaygısından dolayı stres yaşamaları derse yönelik tutumlarını olumsuz etkilemektedir. Derse yönelik tutumun bağımlı değişken olarak alındığı bir regresyon analizi sonucu Tablo 13 'de gösterilmiştir.

Tablo 13. Derse Yönelik Tutum * Gelecek Kaygısı Regresyon Analizi Sonuçları

\begin{tabular}{l|r|r|l|l}
\hline Model & R & R Kare & $\begin{array}{l}\text { Düzeltilmiş R } \\
\text { Kare }\end{array}$ & $\begin{array}{l}\text { Std. Tahmin } \\
\text { Hatası }\end{array}$ \\
\hline 1 &, $185^{\mathrm{a}}$ &, 034 &, 028 & 5,302 \\
\hline \multicolumn{2}{l}{ a. Sabit, Stres 3:Gelecek Kayg1s1 Puanı }
\end{tabular}

a. Sabit, Stres 3:Gelecek Kaygısı Puanı

b. Bağımlı Değişken: Tutum 2:Derse Yönelik Tutum Puanı

\begin{tabular}{l|l|r|r|r|r|r}
\hline \multicolumn{2}{l|}{ Model } & Kareler Toplam & Sd & $\begin{array}{c}\text { Kareler } \\
\text { Ortalamas1 }\end{array}$ & F & $\begin{array}{c}\text { Anlamlılık } \\
\text { Düzeyi } \\
(\mathrm{P})\end{array}$ \\
\hline \multirow{3}{*}{1} & Regression & 169,653 & 1 & 169,653 & 6,035 &, $015^{\text {b }}$ \\
\cline { 2 - 7 } & Residual & 4806,798 & 236 & 28,110 & & \\
\cline { 2 - 8 } & Total & 4976,451 & 237 & & & \\
\hline
\end{tabular}

a. Bağımlı Değişken: Tutum 2:Derse Yönelik Tutum Puanı

b. Sabit, Stres 3:Gelecek Kaygısı Puanı

\begin{tabular}{|c|c|c|c|c|c|c|}
\hline \multicolumn{2}{|c|}{ Model } & \multicolumn{2}{|c|}{ Standartlanmamış Katsayılar } & \multirow{2}{*}{\begin{tabular}{|r|}
$\begin{array}{l}\text { Standardize } \\
\text { Katsay1 }\end{array}$ \\
Beta
\end{tabular}} & \multirow[t]{2}{*}{$\mathrm{t}$} & \multirow{2}{*}{$\begin{array}{l}\text { Anlamlılık } \\
\text { Düzeyi } \\
\text { (P) }\end{array}$} \\
\hline & & B & Std. Hata & & & \\
\hline \multirow[b]{2}{*}{1} & (Sabit) & 23,972 & 1,228 & & 19,514 & ,000 \\
\hline & $\begin{array}{l}\text { STRES 3:GELECEK } \\
\text { KAYGISI PUANI }\end{array}$ &,- 212 & ,086 &,- 185 & $-2,457$ & ,015 \\
\hline
\end{tabular}

Regresyon analizinde gelecek kaygısı stres faktörünün derse yönelik tutumu açıklama gücü $\left(\mathrm{R}^{2}\right) \% 3,4$ ' tür. Sonuçlar anlamlıdır (Sig.<0.05). Basit doğrusal regresyon modeli ise aşağıdaki gibidir:

\section{Derse yönelik tutum $=23,972+$ Gelecek kaygısı stres faktörü $\times(-0,212)$}

$\mathrm{Bu}$ modele göre gelecek kaygısı stres faktöründe 3 maddeden her birine 5 puan verilmesi durumunda 15 ise derse yönelik tutum 20,792 olacak şekilde tahmin 
edilebilmektedir. Öğrencilerin gelecek kaygıları, derse yönelik olumlu tutum düzeylerini olumsuz etkilemektedir.

\section{Derse Yönelik Tutum * Sosyal Çevre ve Ders Stres Faktörü}

Tablo 10'da görüldügüü üzere derse yönelik tutum ile sosyal çevre ve ders stres faktörü arasındaki ilişki negatif ve anlamlıdır. Dolayısıyla öğrencilerin sosyal çevreleri ve derslerle ilgili olarak stres yaşamaları derse yönelik tutumlarını olumsuz etkilemektedir. Derse yönelik tutumun bağımlı değişken olarak alındığı bir regresyon analizi sonucu Tablo 14'te gösterilmiştir.

Tablo 14. Derse Yönelik Tutum * Sosyal Çevre ve Ders Regresyon Analizi Sonuçları

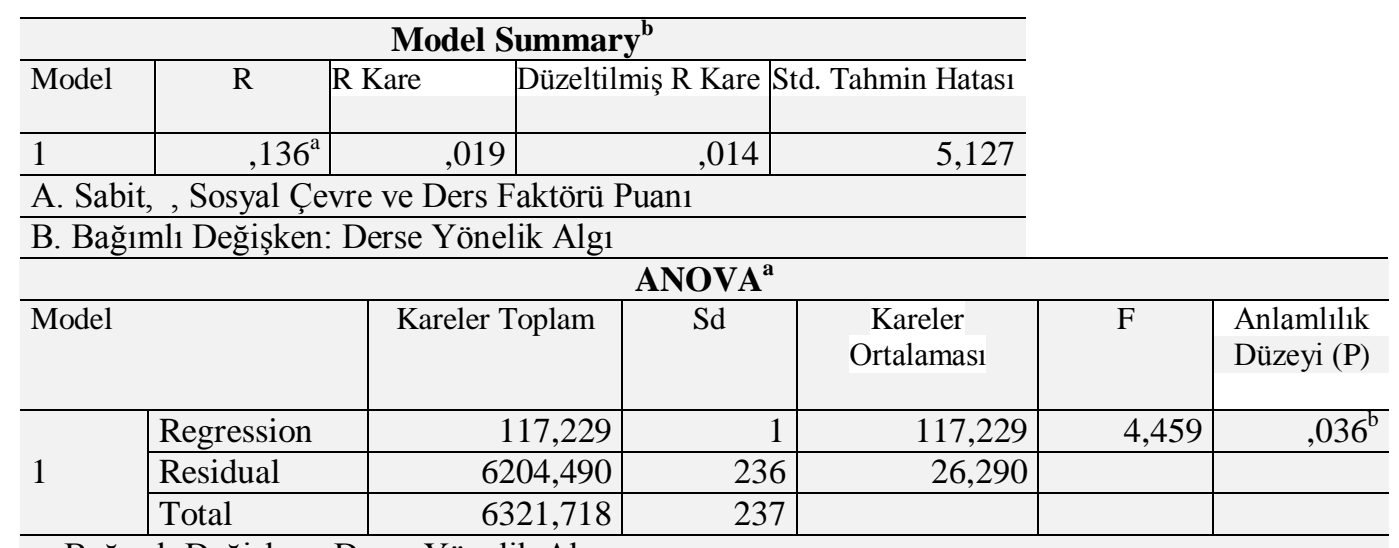

a. Bağımlı Değişken: Derse Yönelik Algı

b. Sabit, Sosyal Çevre Ve Ders Faktörü Puanı

\begin{tabular}{|c|c|c|c|c|c|c|}
\hline \multicolumn{2}{|c|}{ Model } & \multicolumn{2}{|c|}{ Standartlanmamış Katsayılar } & \multirow{2}{*}{\begin{tabular}{|r|}
$\begin{array}{l}\text { Standardize } \\
\text { Katsayı }\end{array}$ \\
Beta \\
\end{tabular}} & \multirow[t]{2}{*}{$\mathrm{t}$} & \multirow{2}{*}{$\begin{array}{l}\text { Anlamlılık } \\
\text { Düzeyi (P) }\end{array}$} \\
\hline & & B & Std. Hata & & & \\
\hline \multirow[b]{2}{*}{1} & (Constant) & 23,092 & ,957 & & 24,140 &, 000 \\
\hline & $\begin{array}{l}\text { SOSYAL ÇEVRE VE } \\
\text { DERS FAKTÖRÜ PUANI }\end{array}$ &,- 163 & ,077 &,- 136 & $-2,112$ & ,036 \\
\hline
\end{tabular}

a. Bağımlı Değiş̧en: Derse Yönelik Algı

Regresyon analizinde gelecek kaygısı stres faktörünün derse yönelik tutumu açıklama gücü $\left(\mathrm{R}^{2}\right) \% 1,9$ ’ dur. Sonuçlar anlamlıdır (Sig.<0.05). Basit doğrusal regresyon modeli ise aşağıdaki gibidir:

\section{Derse yönelik tutum $=23,092+$ Sosyal çevre ve ders faktörü $\times(-0,163)$}

$\mathrm{Bu}$ modele göre sosyal çevre ve ders faktöründe 4 maddeden her birine 5 puan verilmesi durumunda 20 ise derse yönelik tutum 19,832 olacak şekilde tahmin edilebilmektedir. Dolayısıyla öğrencilerin sosyal çevreleri ve derslerin zorluğu nedenleriyle yaşadıkları stres derse yönelik tutumlarını olumsuz etkilemektedir. Aynı analizler dersin hocasına yönelik tutumun bağımlı değişken olduğu durum için de yapılmış ve herhangi bir ilişki tespit edilememiştir. Dolayısıyla öğrencilerin stres durumları dersin hocasına yönelik bakış açılarını veya tutumlarını etkilememektedir. 


\section{4. Öğrencilerde Stres Kaynakları}

Öğrencilerin stres faktörlerinin ölçüldüğü ölçeğe verilen cevaplara ilişkin ortalamalar aşağıdaki Tablo 15 'de gösterilmiştir.

Tablo 15. Stres Ölçeği Ortalamaları

\begin{tabular}{|c|c|c|c|}
\hline İfadeler & Örneklem & Ortalama & Std. Sapma \\
\hline 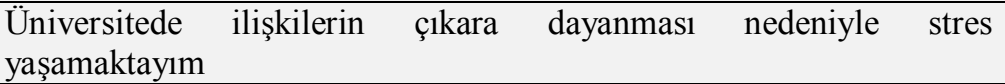 & 238 & 3,12 & 1,497 \\
\hline $\begin{array}{l}\text { Üniversitede kendimi yeterince ifade edememe nedeniyle stres } \\
\text { yaşamaktayım }\end{array}$ & 238 & 2,59 & 1,446 \\
\hline $\begin{array}{l}\text { Üniversitede bana karşı önyargılı tutum ve davranışlar nedeniyle stres } \\
\text { yaşamaktayım }\end{array}$ & 238 & 2,34 & 1,458 \\
\hline $\begin{array}{l}\text { Öğretim elemanları öğrenciler arasında ayrım yapması nedeniyle stres } \\
\text { yaşamaktayım }\end{array}$ & 238 & 2,17 & 1,425 \\
\hline $\begin{array}{l}\text { Ders konularının yeterince anlaşılmaması nedeniyle stres } \\
\text { yaşamaktayım }\end{array}$ & 238 & 2,72 & 1,501 \\
\hline Derslerin yoğunluğu nedeniyle stres yaşamaktayım & 238 & 3,19 & 1,456 \\
\hline Mesleğe yönelik iş bulamama kaygım nedeniyle stres yaşamaktayım & 238 & 3,53 & 1,539 \\
\hline Sınavların ezbere yönelik olması nedeniyle stres yaşamaktayım & 238 & 2,63 & 1,423 \\
\hline Derslerde başarısız olma korkusu nedeniyle stres yaşamaktayım & 238 & 3,42 & 1,467 \\
\hline $\begin{array}{l}\text { Mezuniyet sonrası ne yapacağımı bilememe kaygısı nedeniyle stres } \\
\text { yaşamaktayım }\end{array}$ & 238 & 3,51 & 1,528 \\
\hline $\begin{array}{l}\text { Üniversite hayatımda yaşadığım maddi sıkıntılar nedeniyle stres } \\
\text { yaşamaktayım }\end{array}$ & 238 & 3,02 & 1,451 \\
\hline Örneklem Sayısı & 238 & & \\
\hline
\end{tabular}

Tablo 15 'de görüldüğü üzere öğrenciler üzerinde en fazla stres yaratan "gelecek kaygıs1 faktörü"nü oluşturan maddelerdir. Bu nedenle ikinci aşamada stres ölçeğinde en yüksek düzeyde strese neden olduğu tespit edilen söz konusu 3 madde ile derse bakış açısı ölçeği maddeleri arasındaki korelasyon ilişkilerine bakılmıştır.

Öncelikle "Mesleğe yönelik iş bulamama kaygım nedeniyle stres yaşamaktayım" ifadesine katılım dereceleri ile derse tutum ölçeğindeki maddeler arasındaki ilişkiye bakılmıştır. Sonuçlar Tablo 16'da gösterilmiştir.

Tablo 16'ya göre "Mesleğe yönelik iş bulamama kaygım nedeniyle stres yaşamaktayım" ifadesi ile "Muhasebe dersleriyle ilgili sınavlar ezbere yöneliktir" ifadesine verilen cevaplar arasında negatif ve anlamlı bir ilişki bulunmuştur. "Mesleğe yönelik iş bulamama kaygım nedeniyle stres yaşamaktayım" ifadesi ile "Muhasebe derslerinde başarı notu çok yüksektir" ifadesine verilen cevaplar arasında pozitif ve anlamlı bir ilişki bulunmuştur. "Mesleğe yönelik iş bulamama kaygım nedeniyle stres yaşamaktayım" ifadesi ile "Muhasebe derslerini gerçekten seviyorum" ifadesi arasında negatif ve anlamlı bir ilişki bulunmuştur. "Mesleğe yönelik iş bulamama kaygım nedeniyle stres yaşamaktayım" ifadesi ile "Muhasebe dersleri günlük hayat için çok gereklidir" ifadesi arasında anlamlı ve negatif bir ilişki söz konusudur. Tablodan görüldüğü gibi tek pozitif ilişki başarı notunun yüksek olduğuna yönelik düşünce olan ilişkidir. $\mathrm{Bu}$ sonucun ortaya çıkmasının tutarlı olduğu söylenebilir. Bu durum, öğrenciler başarı notunun yüksek olması nedeniyle dersten başarılı 
olamayacakları korkusu ve dolayısıyla mezun olma ve iş bulma olasılıklarının azalacağı kaygısı yaşayacaklardır şeklinde açıklanabilir.

Tablo 16. "Mesleğe Yönelik İş Bulamama Kaygım Nedeniyle Stres Yaşamaktayım" Maddesinin Korelasyon Analizi

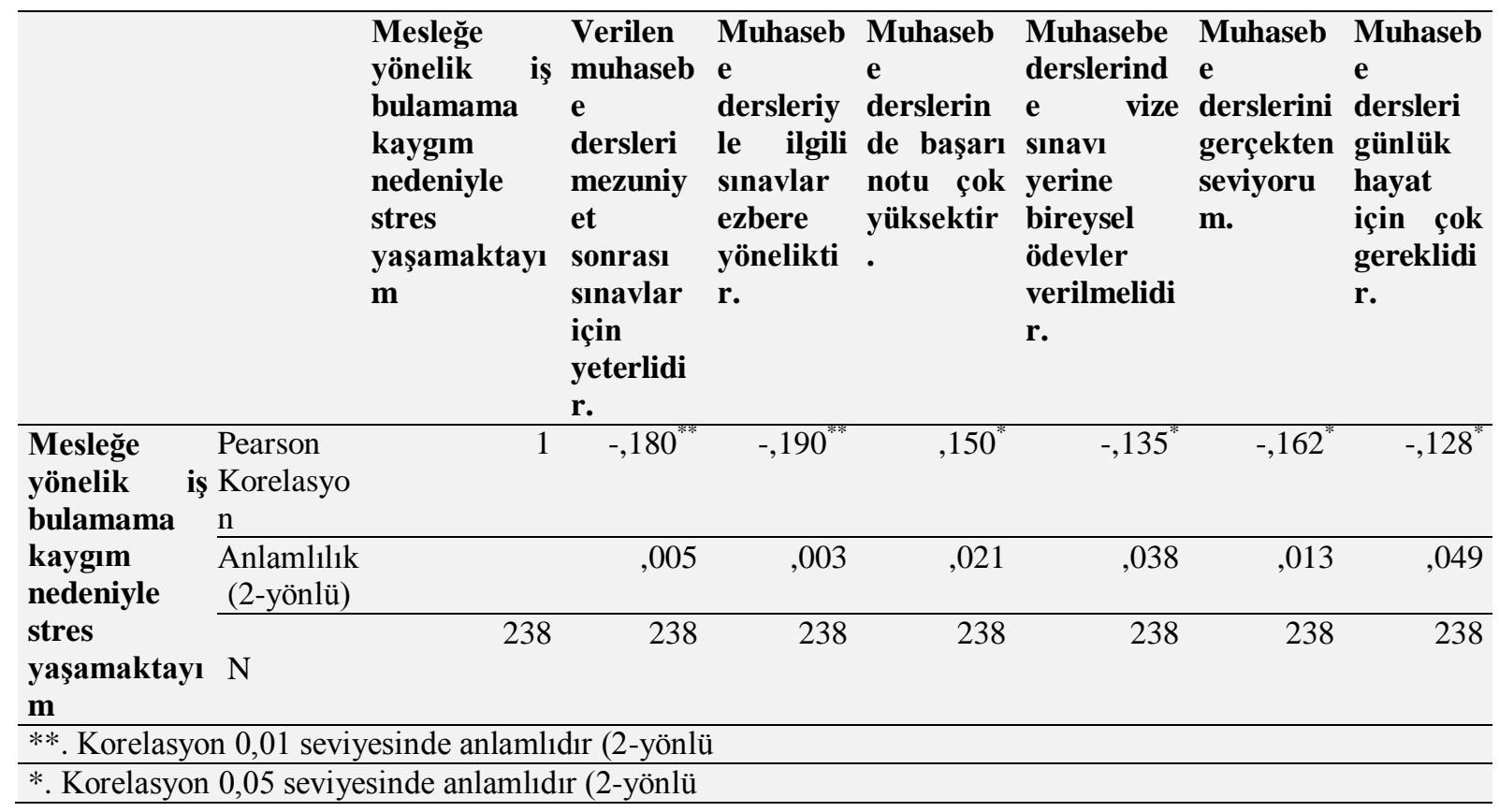

Diğer bir stres faktörü olan "Mezuniyet sonrası ne yapacağımı bilememe kaygısı nedeniyle stres yaşamaktayım" ifadesine katılım dereceleri ile derse karşı tutum ölçeğindeki maddeler arasındaki ilişkiye bakılmıştır. Sonuçlar Tablo 17'de gösterilmiştir.

Tablo 17. "Mezuniyet Sonrası Ne Yapacağımı Bilememe Kaygısı Nedeniyle Stres Yaşamaktayım” Maddesinin Korelasyon Analizi

\begin{tabular}{|c|c|c|c|c|c|}
\hline & $\begin{array}{l}\text { Mezuniyet } \\
\text { sonrası ne } \\
\text { yapacağımı } \\
\text { bilememe } \\
\text { kaygısı } \\
\text { nedeniyle } \\
\text { stres } \\
\text { yaşamaktayım }\end{array}$ & $\begin{array}{l}\text { Muhasebe } \\
\text { dersleriyle } \\
\text { ilgili } \\
\text { sinavlar } \\
\text { ezbere } \\
\text { yöneliktir. }\end{array}$ & $\begin{array}{l}\text { Muhasebe } \\
\text { derslerini } \\
\text { gerçekten } \\
\text { seviyorum. }\end{array}$ & $\begin{array}{l}\text { Muhasebe } \\
\text { alanındaki } \\
\text { gelişmeleri } \\
\text { merak edip } \\
\text { takip } \\
\text { ediyorum. }\end{array}$ & $\begin{array}{l}\text { Muhasebe } \\
\text { hakkında } \\
\text { daha çok } \\
\text { şey } \\
\text { öğrenmek } \\
\text { isterim }\end{array}$ \\
\hline $\begin{array}{l}\text { Mezuniyet sonrası Pearson } \\
\text { ne } \quad \text { yapacağımı Korelasyon }\end{array}$ & 1 &,$- 194^{* * *}$ &,$- 169^{* * *}$ &,$- 153^{*}$ &,$- 139^{*}$ \\
\hline 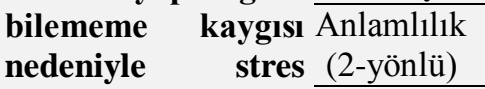 & & ,003 & ,009 & ,018 & ,032 \\
\hline yaşamaktayım $\quad \mathrm{N}$ & 238 & 238 & 238 & 238 & 238 \\
\hline
\end{tabular}


"Mezuniyet sonrası ne yapacağımı bilememe kaygısı nedeniyle stres yaşamaktayım" ifadesi ile "Muhasebe dersleriyle ilgili sinavlar ezbere yöneliktir" ifadesi arasında anlamlı ve negatif bir ilişki vardır. "Mezuniyet sonrası ne yapacağımı bilememe kaygısı nedeniyle stres yaşamaktayım" ifadesi ile "Muhasebe derslerini gerçekten seviyorum" ifadesi arasında anlamlı ve negatif bir ilişki vardır. "Mezuniyet sonrası ne yapacağımı bilememe kaygısı nedeniyle stres yaşamaktayım" ifadesi ile "Muhasebe alanındaki gelişmeleri merak edip takip ediyorum" ifadesi arasında anlamlı ve negatif bir ilişki vardır. "Mezuniyet sonrası ne yapacağımı bilememe kaygısı nedeniyle stres yaşamaktayım" ifadesi ile "Muhasebe hakkında daha çok şey öğrenmek isterim" ifadesi arasında anlamlı ve negatif bir ilişki vardır. Bu sonuçlar, öğrencilerin muhasebe dersleriyle ilgili tutumları ile strese neden olan faktörleri arasında istatistiksel açıdan anlamlı bir ilişki olduğunu göstermektedir. Diğer bir ifadeyle, öğrencilerin muhasebe derslerine ve öğretim elemanına yönelik olumlu tutumlar taşımaları ile strese neden olan faktörlerde azalma olduğunu göstermektedir. Bu çalışma kapsamında tespit edilmiş diğer önemli bir sonuç ise, stres faktörü olan "Derslerde başarısız olma korkusu nedeniyle stres yaşamaktayım" maddesi ise sadece "Öğretim elemanları muhasebe derslerinde anlatılan konulara yeterince hâkimdirler" maddesi ile anlamlı ve pozitif ilişkili bulunmuştur. Sonuçlar Tablo 18' de gösterilmiştir. Bu sonuç öğrencilerin, öğretim elemanlarının muhasebe derslerinde anlattıkları konulara yeterince hakim olduklarında derste başarısız olacaklarını düşündükleri anlamına gelmektedir. Diğer bir ifadeyle öğrencilerin, muhasebe konularına yeterince hakim olan öğretim elemanlarının, sınavlarının da zor olacağı ve bunun sonucunda da sınavlara olumsuz yansıyacağı düşüncesini taşıdıkları görülmektedir.

Tablo 18. "Derslerde Başarısız Olma Korkusu Nedeniyle Stres Yaşamaktayım" Maddesinin Korelasyon Analizi

\begin{tabular}{|c|c|c|c|}
\hline & & $\begin{array}{l}\text { Derslerde başarısız } \\
\text { olma korkusu } \\
\text { nedeniyle stres } \\
\text { yaşamaktayım }\end{array}$ & $\begin{array}{l}\text { Öğretim elemanları } \\
\text { muhasebe } \\
\text { derslerinde } \\
\text { anlatılan konulara } \\
\text { yeterince } \\
\text { hâkimdirler. }\end{array}$ \\
\hline \multirow{3}{*}{$\begin{array}{l}\text { Derslerde başarısız olma korkusu } \\
\text { nedeniyle stres yaşamaktayım }\end{array}$} & $\begin{array}{l}\text { Pearson } \\
\text { Korelasyon }\end{array}$ & 1 &, $151^{*}$ \\
\hline & $\begin{array}{l}\text { Anlamll11k } \\
\text { (2-yönlü) }\end{array}$ & & ,019 \\
\hline & $\mathrm{N}$ & 238 & 238 \\
\hline \multirow{3}{*}{$\begin{array}{lr}\text { Öğretim elemanları muhasebe } \\
\text { derslerinde anlatılan } & \text { konulara } \\
\text { yeterince hâkimdirler. } & \end{array}$} & $\begin{array}{l}\text { Pearson } \\
\text { Korelasyon }\end{array}$ &, $151^{*}$ & 1 \\
\hline & $\begin{array}{l}\text { Anlamlilık } \\
\text { (2-yönlü) }\end{array}$ & ,019 & \\
\hline & $\mathrm{N}$ & 238 & 238 \\
\hline
\end{tabular}




\section{İlişkili Bulunan Demografik Özellikler ile Stres Faktörleri Arasındaki İlişkinin Analizi}

\section{a) Yaş ve Stres}

Tablo 19' a göre öğrencilerin yaşına göre stres düzeyleri arasında anlamlı bir farklılık tespit edilmiştir (sig. 0,030<0,05). Yalnız bu ilişki stres kaynaklarından sosyal çevre ve ders faktörü puanı ile anlamlıdır. Literatürdeki bulgulara göre genç yaştaki bireylerin daha yüksek düzeyde stres yaşadıkları belirtilmektedir. Ancak bu çalışmada yaş arttıkça stresin de arttığ1 görülmektedir. Bunun nedeninin birinci sinıftaki öğrencilerin derslerin ciddiyeti ve zorluğu hakkında yeterli düzeyde farkındalıklarının bulunmaması olduğu düşünülmektedir.

Tablo 19. Yaş ve Stres Değişkenleri Bağımsız Gruplar t Testi

\begin{tabular}{|c|c|c|c|c|c|c|}
\hline \multicolumn{7}{|c|}{ Grup İstatistikleri } \\
\hline & \multicolumn{2}{|c|}{ YAŞ } & Örneklem & Ortalama & Std. Sapma & Std. Error Mean \\
\hline \multirow{2}{*}{$\begin{array}{c}\text { Sosyal Çevre ve Ders Faktörü } \\
\text { Puanı }\end{array}$} & $17-20$ & & 132 & 11,08 & 4,173 &, 363 \\
\hline & $21-24$ & & 106 & 12,29 & 4,410 & ,428 \\
\hline \multicolumn{7}{|c|}{ Bağımsız Gruplar t Testi } \\
\hline & \multicolumn{2}{|c|}{$\begin{array}{l}\text { Varyansların } \\
\text { eșitliği testi }\end{array}$} & \multicolumn{4}{|c|}{ Ortalamaların Eşitliği Testi } \\
\hline & $\mathrm{F}$ & $\begin{array}{c}\text { Anlamlılık } \\
\text { Düzeyi } \\
\text { (P) }\end{array}$ & $\mathrm{t}$ & df & \multicolumn{2}{|c|}{$\begin{array}{l}\text { Anlamlılık } \\
\text { Düzeyi (P) }\end{array}$} \\
\hline $\begin{array}{l}\text { Sosyal Çevre ve Ders } \\
\text { Faktörü Puanı }\end{array}$ & ,370 & ,543 & $-2,180$ & 236 & &, 030 \\
\hline
\end{tabular}

\section{b) Cinsiyet ve Stres}

Literatür bölümünde ifade edilen çalışmalarda kadın öğrencilerin erkek öğrencilerden daha fazla stres yaşadıkları belirtilmektedir. Bu çalışmada da literatürdeki bulgulara uygun bir sonuç elde edilmiştir. Tablo 20'ye göre Sosyal Çevre ve Ders stres faktörü dikkate alındığında kadınların erkeklerden istatistiksel olarak anlamlı (sig. $0,036<0,05)$ derecede daha yüksek stres yaşadıkları görülmektedir.

Tablo 20. Yaş ve Stres Değişkenleri Bağımsız Gruplar t Testi

\begin{tabular}{|c|c|c|c|c|c|c|}
\hline \multicolumn{7}{|c|}{ Grup İstatistikleri } \\
\hline & CINS & & Örneklem & Ortalama & Std. Sapma & Std. Error Mean \\
\hline \multirow{2}{*}{$\begin{array}{c}\text { Sosyal Çevre ve Ders Faktörü } \\
\text { Puanı }\end{array}$} & & & 122 & 12,19 & 4,288 &, 388 \\
\hline & & & 116 & 11,02 & 4,277 & ,397 \\
\hline \multicolumn{7}{|c|}{ Bağımsız Gruplar t Testi } \\
\hline & \multicolumn{3}{|c|}{ Varyansların eșitliği testi } & \multicolumn{3}{|c|}{ Ortalamaların Eşitliği Testi } \\
\hline & $\mathrm{F}$ & \multicolumn{2}{|c|}{$\begin{array}{l}\text { Anlamlılık } \\
\text { Düzeyi (P) }\end{array}$} & $\mathrm{t}$ & $\mathrm{df}$ & $\begin{array}{l}\text { Anlamlılık } \\
\text { Düzeyi (P) }\end{array}$ \\
\hline $\begin{array}{c}\text { Sosyal Çevre ve Ders Faktörü } \\
\text { Puanı }\end{array}$ &, 158 & & ,691 & 2,109 & 236 & ,036 \\
\hline
\end{tabular}




\section{c) Sinif ve Stres}

Yaş ve stres ilişkisine benzer bir ilişki ortaya çıkmıştır. Öğrencilerin sınıflarına göre stres düzeyleri arasında anlamlı bir farklılık vardır (sig. 0,006<0,05). Bu farklılığın hangi gruplar arasında ortaya çıktığının tespit edilebilmesi amacıyla Post Hoc testi gerçekleştirilmiştir. Post hoc testlerinden biri olan ve her gruba düşen örneklem sayısının eşit olmaması durumunda gruplar arası farklılığın hangi gruplardan kaynaklandığını tespit etmek için kullanılan Scheffe testi sonucunda söz konusu farklılığın birinci ve ikinci sınıflar arasında söz konusu olduğu tespit edilmiştir. Buna göre ikinci sınıflarda stres faktörü birinci sinıflardan daha yüksektir.

Tablo 21. Sınıf ve Stres Değişkenleri Bağımsız Gruplar t Testi

\begin{tabular}{|c|c|c|c|c|}
\hline \multicolumn{2}{|c|}{ Tanımlayıcı İstatistikler } & Örneklem & Ortalama & Std. Sapma \\
\hline \multirow{5}{*}{ Sosyal Çevre ve Ders Faktörü Puanı } & Birinci & 86 & 10,83 & 4,159 \\
\hline & İkinci & 46 & 13,04 & 3,306 \\
\hline & Üçüncü & 73 & 12,22 & 4,741 \\
\hline & Dördüncü & 33 & 10,36 & 4,343 \\
\hline & Toplam & 238 & 11,62 & 4,314 \\
\hline \multicolumn{2}{|c|}{ ANOVA Testi } & $\mathrm{df}$ & $\mathrm{F}$ & $\begin{array}{l}\text { Anlamlılık } \\
\text { Düzeyi (P) }\end{array}$ \\
\hline \multirow{3}{*}{ Sosyal Çevre ve Ders Faktörü Puanı } & Gruplararas1 & 3 & 4,209 & 006 \\
\hline & Grupiçi & 234 & & \\
\hline & Toplam & 237 & & \\
\hline
\end{tabular}

\section{SONUÇ VE DEĞERLENDİRME}

Bu çalışmada, lisans düzeyinde muhasebe eğitimi alan öğrencilerde strese neden olan faktörlerle derse yönelik tutumları arasındaki ilişki araştırılmıştır. Bu bağlamda, Çankırı Karatekin Üniversitesi IIIBF 2017-2018 eğitim ve öğretim dönemi bahar yarıyılında eğitim gören öğrencilere yönelik anket uygulanmış ve elde edilen 238 adet anket değerlemeye alınmıştır. Anket, öğrencilerin demografik yapılarının belirlenmesi ve öğrencilerde strese neden olan faktörler ile muhasebe derslerine tutumlar ile bunlar arasındaki ilişkilerin belirlenmesine yönelik üç bölümden oluşmaktadır. Çalışmada öğrencilerin sorulara verdikleri yanıtlar SPSS 21.0" istatistik paket programı kullanılmıştır. Verilerin çözümlenmesinde Frekans Analizi, T Testi ve Tek Yönlü Varyans Analizi teknikleri kullanılarak analiz edilmiştir.

Çalışma sonucunda $\mathrm{H} 1$ ve $\mathrm{H} 2$ hipotezleri doğrulanmıştır. Öğrencilerin dersin hocasına yönelik bakış açıları ile derse yönelik bakış açıları arasında anlamlı bir ilişki tespit edilmiştir. Aynı zamanda stres faktörü öğrencilerin derse bakış açılarını etkileyen anlamlı bir faktördür. Sınıf ve yaş özellikleri ile stres arasındaki ilişki, bu grup öğrencilerin kişisel özelliklerinin ve öğrencilerin üniversite hayatı tecrübesinin incelenmesiyle açıklanabilir. Muhasebe dersleri bilindiği gibi genellikle öğrenciler için zorlayıcı olarak daha fazla çalışma ve yetenek gerektiren doğası gereği nicel derslerdir. Buna ek olarak, yaşça daha genç veya üniversite öğreniminin daha ilk dönemlerinde olan öğrenciler, daha üst yarıyllarda okuyan öğrencilerin derslere ve sınavlara yönelik kazanmış oldukları tecrübe ve becerileri geliştirmek 
için zamana ihtiyaç duyarlar. Bu nedenle daha üst sınıflarda okuyan öğrencilerde daha az stres görülür. Sonuçlar, üniversite öğretim kadrosuna, muhasebe dersleri öğretim üyelerine ve muhasebe kurslarına katılan yöneticilere faydalı bilgiler sunmaktadır. Sonuçlar ayrıca eğitim ve danışmanlık hizmetleri için yararlı bilgiler sunmaktadır. $\mathrm{Bu}$ çalışma, üniversitelerin akademik stresi daha iyi yönlendirmesine yardımcı olabilir, böylece muhasebe öğrencileri için deneyim ve yaşam kalitesinde iyileşmelere yol açabilir.

$\mathrm{Bu}$ çalışma, araştırmanın yapıldı̆̆ yönelik tutumları ve stres nedenleriyle ilgili bazı faktörleri ortaya koymaktadır. Elde edilen sonuçlar, diğer üniversite öğrencileri ve ön lisans öğrencileri için genelleştirilmemekle birlikte, diğer üniversitelerdeki öğrencilerin muhasebe derslerine yönelik tutumları ve stres durumları hakkında genel bir bilgi verebilir. Diğer üniversitelerde yapılacak olan benzer veya karşılaştırmalı çalışmalar, konunun daha iyi anlaşılmasına katkı sağlayacaktır. Ayrıca gelecekteki çalışmalarda ankette yer alan sorular genişletilerek ve farklı analizler kullanılabilir. Buna ek olarak öğrencilerin muhasebe mesleğini seçme nedenleriyle stres faktörü de araştırılabilir.

\section{KAYNAKLAR}

Abouserie, R. (1994). Sources and Levels Of Stress İn Relation to Locus Of Control And Self Esteem İn University Students. Educational Psychology, 14(3), pp.323-330.

Akbulut, Halim - Pekkaya, Mehmet - Aksakaloğlu, Hakan, (2014), "Meslek Mensuplarının Bakış Açısıyla Ticaret Meslek Liselerindeki Muhasebe Eğitimi: Bursa İli Üzerine Bir Uygulama", Muhasebe ve Finansman Dergisi, 62 (2), ss. 73-91.

Aşc1, Ö.- Hazar, G. - K1lıç, E. - Korkmaz, A. (2015). Üniversite Öğrencilerinde Stres Nedenlerinin Ve Stresle Başa Çıkma Biçimlerinin Belirlenmesi, Uşak Üniversitesi Sosyal Bilimler Dergisi; Y11: 2015, Say1: 24.

Bekçi, İ. - Ömürbek, V. - Tekşen, Ö. (2007), "Muhasebe Meslek Mensuplarında Stres Kaynağının Belirlenmesine Yönelik Bir Araştırma”, Süleyman Demirel Üniversitesi İktisadi ve İdari Bilimler Fakültesi Dergisi, 12 (1), ss. 145-161.

Büyükarıkan, B. - Büyükarıkan, U. (2014), "Lisans Düzeyinde Muhasebe Eğitimi Alan Öğrencilerin Başarılarını Etkileyen Faktörlerin Analizi”, Mehmet Akif Ersoy Üniversitesi Eğitim Bilimleri Enstitüsü Dergisi, 3(5), ss. 65-79.

Cahir, N., - Morris, R. D. (1991), The Psychology Student Stress Questionnaire. Journal Of Clinical Psychology, 47(3), pp.414-417.

Coşkun, S. - Kır, A. - Özbay, F. (2017), "Meslek Yüksekokulu Muhasebe Bölümü Öğrencilerinin Muhasebe Eğitimine Bakış Açılarının ve Mesleki Eğitimden Beklentilerinin Değerlendirilmesi”, Uluslararası Yönetim İktisat ve İşletme Dergisi, 13(5), ss. 314-329.

Çakır, N. - Canbaz, S. - Gümüş, S. (2014), "Meslek Yüksekokulu Öğrencilerinin Muhasebe Eğitimindeki Algı ve Beklentilerinin Belirlenmesine Yönelik Bir Araştırma: 
Uzunköprü MYO Örneği”, Uluslararası Hakemli Pazarlama ve Pazar Araştırmaları Dergisi, 2 (1), ss. 78-94.

Eren, E., (2004), Örgütsel Davranış ve Yönetim Psikolojisi, Beta Yayıncılık, İstanbul.

Erol, M. - Erkan, G. (2008), "Lisans Düzeyinde Muhasebe Eğitimi Alan Öğrencilerin Başarılarını Etkileyen Faktörlerin Belirlenmesine Yönelik Biga İktisadi ve İdari Birimler Fakültesinde Bir Araştırma", Karamanoğlu Mehmetbey Üniversitesi İİBF Dergisi, 10(14), ss. 140-165.

Ertuğrul İ. - Özdemir S. (2014), Muhasebe Dersi Alan Ön Lisans ve Lisans Öğrencilerinin Derse Yönelik Tutumlarının Tespiti: Ege Bölgesinde Bir Uygulama”, Niğde Üniversitesi İktisadi İdari Bilimler Fakültesi Dergisi, 7 (1), ss. 204-214.

Gabre, H. - Kumar, G. (2012), "The Effects Of Perceived Stress And Facebook On Accounting Students' Academic Performance", Accounting and Finance Research, 1(2), pp. 87-99.

Gadzella, B. M., Masten, W. G., \& Stacks, J. (1998), "Students' Stress And Their Learning Strategies, Test Anxiety And Attributions", College Student Journal, 32(3), pp.416423.

Gökçen, G. (1998), "Uygulamacıların Muhasebe Eğitiminden Beklentileri”, Muhasebe Finansman Dergisi, T.C. Marmara Üniversitesi Muhasebe Araştırma Merkezi, 7(9).

Güçlü, N. (2001). "Stres Yönetimi.” Gazi Üniversitesi Eğitim Fakültesi Dergisi, 21(1), ss. 91109.

Gümüştekin, G. E. - Öztemiz,A. B. (2005), “Örgütlerde Stresin Verimlilik ve Performansla Etkileşimi”, Çukurova Üniversitesi Sosyal Bilimler Enstitüsü Dergisi, 14(1), ss. 271287.

Hacıhasanoğlu, T. - Karaca, N. (2014), "Bağımsız Çalışan Muhasebe Meslek Mensuplarının Ve Muhasebe Çalışanlarının Tükenmişlik, İş Tatmini ve Stres Düzeylerinin Belirlenmesine Yönelik Bir Alan Araştırması", Süleyman Demirel Üniversitesi İ.İ.B.F. Dergisi, 19(4), ss. 153-170.

Hamid, J. A., - Zaidatol, A. P. (2004). Students' perception of the quality of teaching and learning in Business Studies Programs. Pertanika Journal of Social Sciences and Hummanities, 12(1), 71-86.

How, Z. J. - Shinde, J. S. - Willems, J. (2013), “Academic Stress in Accounting Students: An Empirical Study", Asian Journal of Accounting and Governance, 1(4), pp. 1-10.

Kandemir, T. - Kardeş, Z. - Baykut, E. (2016), "Meslek Yüksekokulu Öğrencilerinin Muhasebe Eğitimine Bakış Açıları: Afyon Kocatepe Üniversitesi Meslek Yüksekokulları Örneği'”, Afyon Kocatepe Üniversitesi Sosyal Bilimler Dergisi, 18(2), ss. 133-151. 
Kaplanoğlu, E. (2014). "Mesleki Stresin Temel Nedenleri Ve Muhtemel Sonuçları: Manisa İlindeki SMMM'ler Üzerine Bir Araştırma”, Muhasebe ve Finansman Dergisi, 64(4), ss. 131-150.

Karlıklı, M. (2016), “Ortaöğretim Kurumlarında Verilen Muhasebe Eğitiminin Muhasebecilik Mesleğine Uygunluğunun Değerlendirilmesi”, Karadeniz Teknik Üniversitesi Sosyal Bilimler Enstitüsü, 6(1), ss. 150-165.

Kayıhan, B. - Tepeli, Y. (2015), "Muhasebe ve Vergi Bölümlerindeki Muhasebe Eğitimi: Muğla Sitkı Koçman Üniversitesi Meslek Yüksekokulları Arası Karşılaştırma, Akademik Sosyal Araştırmalar Dergisi, 3(10), ss. 487-502.

Kutlu, H. A. - Öztürk, S., Yılmaz, T. - Gerekan, B. (2017), "Muhasebe Eğitiminde Ölçme Ve Değerlendirme: Öğrencilerin Bakışı Üzerine Bir Araştırma", Muhasebe ve Finans Dergisi, 74(1), ss. 15-36.

Latif, E. - Miles, S. (2013), "Students'perception of Effectıve Teaching", Journal of Economics and Economic Education Research, 14(1), pp. 121-140.

Lavin, A. M. - Davies, T. L. - Carr, D. L. (2010), “The Impact of Instructor Attire on Student Perceptions of Faculty Credibility and Their Own Resultant Behavior", American Journal of Business Education, 3(6), pp. 51-70.

McEwan, L. - Goldenberg, D. (1999), "Achievement motivation, anxiety and academic success in first year Master of Nursing students", Nurse Education Today, 19(5), pp. 419-430.

Mechanic, D. (1978), Students Under Stress: A Study in The Social Psychology of Adaptation,London, Madison: University of Wisconsin Press.

Mısırlı, İ. (2004), Genel ve Teknik İletişim, Detay yayıncılık, Ankara.

Misra, R. - McKean, M. - West, S. - Russo, T. (2000), “Academic Stress of College Students: Comparison of student and faculty perceptions", College Student Journal, 34(2), pp. 236-246.

Otlu, F. - Durmuş, A.F. - Solak, B. (2012), "Meslek Yüksekokulları Muhasebe ve Vergi Bölümlerindeki Muhasebe Eğitimi ve Bölümün Geleceği Hakkında Bir Araştırma: Malatya Meslek Yüksekokulu Uygulaması", Muhasebe ve Finansman Dergisi, 55(2), ss. 35-50.

Pehlivan, İ. (1995), Yönetimde Stres Kaynakları, Personel Geliştirme Merkezi Yayınları, Ankara.

Robotham, D. (2008), "Stress Among Higher Education Students: Towards a Research Agenda. Higher Education, 56(6), pp. 735-746.

Schafer, W. (1996), Stress Management for Wellness. (3rd ed.) Fort Worth: Harcourt Brace College Publishers. 
Shah, S. A. (2009), "Impact of Teacher's Behaviour on the Academic Achievement of University Students”, Journal of College Teaching \& Learning, 6(1), pp. 69-74.

Smith, K. J. - Rosenberg, D. L. - Timothy Haight, G. (2014), “An Assessment of the Psychometric Properties of the Perceived Stress Scale- 10 (PSS10) with Business and Accounting Students", Accounting Perspectives, 13(1), pp. 29-59.

Şeker, Y. - İşleyen, A. (2017), "Muhasebe Derslerine Karşı Öğrenci Tutumlarının İncelenmesine Yönelik Bir Araştırma”, Sosyal ve Beşeri Bilimler Araştırmaları, Çizgi Kitabevi.

Yıldırım, O. - Tektüfekçi, F. - Çukacı, Y.C. (2004), "Modern Toplum Hastalığı: Stres ve Muhasebe Meslek Elemanı Üzerindeki Etkileri”, Süleyman Demirel Üniversitesi İ.İ.B.F. Dergisi, 9(2). ss. 1-19.

Yıldız, Ş. - Ülkü, S. (2015), "Muhasebe Eğitimi Alan Öğrencilerin Öğrenim Kazanımları Üzerine Bir Araştırma: Sakarya Üniversitesi Örneği”, Muhasebe Bilim Dünyası Dergisi, 17(4), ss. 120-165.

Zeytin, M. - Gökgöz, A. (2011), "Muhasebe Meslek Mensuplarında Strese Neden Olan Faktörlerin İncelenmesi: Yalova ve Bilecik İlleri Örneği”, Gümüşhane Üniversitesi Sosyal Bilimler Elektronik Dergisi, 3(2), ss. 99-118.

Zeytin, M. (2016). “Lisans Düzeyinde Muhasebe Eğitimi”, Türkiye'de Muhasebe Eğitimi, Der: Ahmet Gökgöz, Bursa: Ekin Basım Yayın Dağıtım, ss.107-156. 